\title{
Rediscovering the mosquito fauna (Diptera: Culicidae) of Estonia: an annotated checklist with distribution maps and DNA evidence
}

\author{
HELI KIRIK ${ }^{1,2 *}$, LEA TUMMELEHT ${ }^{4} \&$ OLAVI KURINA ${ }^{1,3}$ \\ ${ }^{1}$ Estonian University of Life Sciences, Inst of Agricultural and Environmental Sciences, Friedrich Reinhold Kreutzwaldi 5D, 51006 \\ Tartu, Estonia

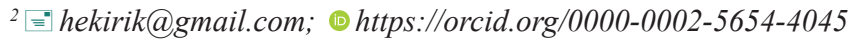 \\ ${ }^{3} \equiv=$ olavi.kurina@emu.ee; @ https://orcid.org/0000-0002-4858-4629 \\ ${ }^{4}$ Estonian University of Life Sciences, Inst of Veterinary Medicine and Animal Sciences, Friedrich Reinhold Kreutzwaldi 62, 51006 \\ Tartu, Estonia \\ "lea.tummeleht@gmail.com; @ https://orcid.org/0000-0002-6478-7047 \\ ${ }^{*}$ Corresponding author
}

\begin{abstract}
Female mosquitoes (Diptera: Culicidae) affect their hosts in numerous negative ways and are crucial to the spread of vector-borne pathogens. It is, therefore, important to have a detailed overview of regional mosquitoes, to be able to detect changes in species diversity and identify possible health threats. The aim of this study was to update the checklist of the mosquito fauna of Estonia for the first time since 1957. For this purpose, 24,344 adult mosquitoes (94\% females) were collected in Estonia from 2008 to 2020 using various trapping methods. Specimens were primarily identified by morphological characteristics, but DNA barcoding based on the partial cytochrome c oxidase subunit 1 gene (COI) was also used. Species were included in the checklist based on historical records as well as new collections, while also considering reports from neighboring countries. Species records are supplemented with voucher specimens, distribution maps and DNA evidence. The updated checklist includes 34 species, 27 of which were confirmed with recently collected material. All in all, Aedes communis (de Geer, 1776) proved to be the most common mosquito in Estonia, accounting for $30.1 \%$ of the specimens collected. This is noteworthy, as this species has been implicated in the transmission of multiple disease agents present in the area. New evidence revealed the presence of Ae. hexodontus Dyar, 1916, Ae. sticticus (Meigen, 1838), Anopheles messeae Falleroni, 1926 and Culiseta bergrothi (Edwards, 1921) in Estonia.
\end{abstract}

Key words: Aedes, Anopheles, Coquillettidia, Culex, Culiseta, DNA barcoding, entomology, Estonia

\section{Introduction}

Mosquitoes (Diptera: Culicidae) are a notable group of insects, as they can affect the wellbeing of humans and animals alike. The haematophagous females of many mosquito species can be a serious biting nuisance, as well as transmit various pathogens. Illnesses caused by vector-borne pathogens affect more than one billion people per year, with diseases caused by mosquito-borne pathogens being responsible for the majority of the infections (WHO 2014). Furthermore, these diseases cause not only death and disability, but also notable monetary loss, further exacerbating economic inequality, as poorer populations are more vulnerable to insect bites (WHO 2017). Blood seeking mosquitoes can also be a nuisance in their own right, disrupting outdoor activities and creating considerable stress in humans and animals (Islam et al. 2017). For these reasons, mosquitoes continue to be an important subject of study, as better understanding of their biology and ecology can help predict changes and create strategies to mitigate some of the harmful effects. Mosquito species richness varies based on geographic location, with areas close to the equator supporting a greater number of species than regions at higher latitudes (Foley et al. 2007). This diversity makes mosquitoes especially significant in the tropics. However, some important species, a number of which are known to be competent vectors of pathogenic agents, can be found in colder climates as well (Martinet et al. 2019). This trend is mirrored by mosquito-borne pathogens: while the majority are confined to warm climates, a number of diseases also occur in higher latitudes and many infections are now emerging or re-emerging (Bale 2012; Liang 
et al. 2015; Evans \& Peterson 2019). In fact, throughout recent decades, there have been noticeable changes in the geographic distributions of both biting insects as well as vector-borne pathogens (Medlock et al. 2012; Brugueras et al. 2020). Such shifts have been driven by numerous anthropogenic and environmental factors, such as global transport routes, changes in land use, urbanization, extreme weather events and climatic fluctuations, among others (Hui 2006; Zell et al. 2008). These aspects can also cause significant changes in the relative and absolute abundance of indigenous mosquito species (Franklinos et al. 2019; Câmara et al. 2020). As a result, calls have been made for increased mosquito surveillance as well as additional empirical studies to investigate vector ecology in the changing world (Franklinos et al. 2019).

More than half of the eight Nordic-Baltic countries, as well as the neighboring Russian Federation, have published at least one update to their mosquito checklists during the last few decades. For example, a literature based list of Lithuanian Diptera was published in 2000 and included 36 mosquito species, listing five species in the genus Anopheles Meigen, 1818, 23 in genus Aedes Meigen, 1818, three in Culex Linnaeus, 1758, four in Culiseta Felt, 1904 and the species Coquillettidia richiardii (Ficalbi, 1889) (Pakalniškis et al. 2000). Eleven years later, the official number of Lithuanian mosquitoes rose to 37, with the addition of Aedes geminus Peus, 1970 (Bernotiene \& Lučiūnaitè 2011). Meanwhile, only 25 mosquito species had been reported from Latvia: four species of Anopheles, 17 species of Aedes, one species of Coquillettidia Dyar, 1905 and Culex, as well as two species of the genus Culiseta, as reported by Spungis (2000). However, the author of the aforementioned study concluded that the real number of mosquitoes in Latvia was likely to be significantly higher. During this time, the mosquito checklist for European Russia was also revised, with the update featuring 64 species, including four species with doubtful presence (Gornostaeva 2000). The Swedish mosquito fauna has been relatively well researched from 2000 onwards. The most recent checklist for Sweden, based on both prior literature records and new collection efforts (Lundström et al. 2013), included 49 mosquito species: seven belonging to the genus Anopheles, 31 to Aedes, one to Coquillettidia, three to Culex and another seven to Culiseta. At the moment, 55 mosquito species are thought to be present in Sweden (Möhlmann et al., 2017; Robert et al. 2019). The mosquito fauna of Finland has been updated multiple times in the last decade. First of these was a literature review listing 38 mosquito species (Huldén \& Huldén 2014), but this information was further built upon and corrected in later articles (Culverwell 2018; Culverwell et al. 2020; Culverwell et al. 2021), with the most recent list including 43 species. Similarly, a recent comprehensive overview was written about the mosquitoes of northwestern Russia, reporting a total of 46 species and comparing the results to data from neighboring countries (Khalin \& Aibulatov 2020). This was followed by a publication about the northernmost records of these mosquito species (Khalin \& Aibulatov 2021). In contrast, the most recent checklist of the mosquitoes of Estonia was published in the mid-Twentieth Century (Remm 1957).

Few people have studied mosquitoes in the area of present-day Estonia. Some of the earliest records concerning the Baltic mosquito fauna can be found from the first half of the Nineteenth Century onwards, attributable to the Baltic German entomologists B. A. Gimmerthal (1779-1848) and F. L. F. Sintenis (1835-1911), as well as some visiting scientists, e.g. A. Dampf Tenson (1884-1948) (Remm 1955). The first extensive research on haematophagous Diptera in Estonia was conducted during the mid-Twentieth Century. This culminated in 1955, when H. Remm (1929-1986) completed a dissertation featuring an annotated checklist of the mosquitoes of Estonia. The manuscript was based on 12,204 specimens collected from 300 study sites, as well as available museum collections, encompassing 30 mosquito species (Remm 1955). This work was published two years later in the journal Entomologicheskoe Obozrenie (Remm 1957). Afterwards, new entries relating to mosquito species present in Estonia have been few and far between. Burtin (2014) defended a master's theses updating previous species records with currently valid synonyms and presented a study based on 691 new mosquito specimens. The manuscript included a list of 33 mosquito species likely to be present in the country, and two species suspected to occur in the country. Some of this information was later published as part of a larger study concerning urban mosquitoes, along with 1,199 additional observations (Kirik et al. 2021). Many of the mosquito species suspected to be present in Estonia were still missing reliable up to date records. Furthermore, information regarding the distribution and abundance of these mosquitoes had not been substantially updated after the contributions of Remm (1955). To remedy this, an updated checklist, supplemented with new evidence, was needed to better understand the mosquito fauna of the country. This would allow future researchers to track changes in species composition as well as better assess the risk of diseases caused by vector-borne pathogens in the region. Consequently, the aim of this study was to provide an updated checklist of the mosquitoes present in Estonia, along with voucher material, distribution maps, partial cytochrome c oxidase (MT-CO1) sequences and comments concerning the abundance of each species. 


\section{Material and methods}

Study area. Estonia is the northernmost country of the three Baltic nations: it is located on the eastern shore of the Baltic Sea and shares a land border with Latvia and Russia. Estonia is situated on the East-European Plain and is therefore relatively flat, with a mean altitude of about $50 \mathrm{~m}$ above sea level (Raukas 1995). The country has a population density of 30.6 inhabitants per $\mathrm{km}^{2}$, which is relatively low compared to other European nations (Eurostat 2021; Statistics Estonia 2020). Furthermore, 51.4\% (relative error (RE) $\pm 1.1 \%$ ) of Estonia is consists of forests, $27.0 \%(\mathrm{RE} \pm 1.9 \%)$ of the land is in agricultural use and bogs and inland waters make up 4.9\% (RE $\pm 5.1 \%)$ and $1.7 \%$ ( $\mathrm{RE} \pm 8.8 \%$ ) of the country, respectively (Environment Agency 2020). Estonia is considered to be part of the Boreal Region according to the European Commission (Sundseth et al. 2009), but belongs to the temperate continental climate zone with warm summers based on the updated Köppen-Geiger classification system (Kottek et al. 2006; Beck et al. 2018).

Mosquito collection. Adult mosquitoes were collected from 2008 to 2020 from various locations in Estonia, both from the mainland and the three largest islands: Saaremaa, Hiiumaa and Muhu (Fig. 1). Fieldwork took place from the start of May until mid-October, and included collection sites in the countryside, suburbs and urban greenspaces. In rural areas, mosquitoes were collected in farmyards, pastures, lakesides, wetlands and forest. Collection points were chosen to cover as many biomes as possible, while allowing insect traps to be emptied regularly and be supervised by volunteers. Collection sites were sampled for different periods of time due to both limited personnel and the variety of different collection methods. Most specimens were caught with the battery powered Mosquito Magnet Independence traps (Woodstream Corp., Lancaster, USA) baited with Octenol $\left(\mathrm{C}_{8} \mathrm{H}_{16} \mathrm{O}\right)$, but mosquitoes were also collected with sweep nets, EVS light traps (BioQuip Products, Rancho Dominguez, USA) baited with dry ice, Malaise traps (cf. Tomasson et al. 2014) and window traps (cf. Sammet et al. 2016). Mosquito Magnet and EVS traps were emptied every two to four days, but Malaise and window traps were emptied a few times over the summer. Information concerning the use of sweep nets can be found in a previous publication (Kirik et al. 2021). It is important to note that Mosquito Magnet and EVS traps use bait to attract host seeking arthropods and therefore predominantly capture female mosquitoes. As a result, the newly acquired data for the checklist primarily consists of information obtained from the collection of females.

The majority of mosquitoes were stored in tubes at $-20^{\circ} \mathrm{C}$ as dry material, but some older samples were kept in $76 \%$ ethanol at $4^{\circ} \mathrm{C}$ or at room temperature. Mosquitoes were identified to species or species-group level by the first author based on morphological markers, using keys of Becker et al. (2020). The resulting identifications were used to make general inferences concerning the prevalence of each taxonomic group. Based on the number of individuals collected from 2008 to 2020, species were designated as abundant ( $>1,001$ individuals), common (501-1,000 individuals), infrequent (101-500 individuals) or rare ( $<100$ individuals) for ease of discussion. Maps showing the new and historic collection sites of each species were constructed using Adobe Photoshop CS5 Extended (Adobe, San Jose, USA) and arranged into figures. Up to three mosquitoes from every species collected were selected as voucher specimens, pinned and stored at room temperature in the Entomological Collection [IZBE] of the Estonian University of Life Sciences. The remainder of the material is also stored in the university. At least one voucher specimen of each species was subjected to DNA barcoding to further validate species identification and to help distinguish morphologically similar or isomorphic species.

DNA analysis. DNA extraction was carried out using one to three legs from each mosquito. The material was homogenized with the handheld Kontes Pellet Pestle (DWK Life Sciences GmbH, Mainz, Germany) and DNA extraction was completed using the DNeasy Blood \& Tissue Kit (Qiagen, Hilden, Germany) following the manufacturer's instructions. Species identification was carried out based on the $710 \mathrm{bp}$ partial sequence of the cytochrome c oxidase subunit 1 gene (COI), using the universal primers LCO1490 (5'- GGTCAACAAATCATAAAGATATTGG3') and HCO2198 (5' - TAAACTTCAGGGTGACCAAAAAATCA-3') (Folmer et al. 1994). Additionally, 16 Culex pipiens mosquitoes were analyzed for the presence of the intercellular bacteria, Wolbachia, based on the symbionts wsp gene. This was done using primers wsp-81F (5'- TGGTCCAATAAGTGATGAAGAAAC -3') and wsp-691R (5'- AAAAATTAAACGCTACTCCA -3') (Braig et al. 1998). All polymerase chain reaction (PCR) mixtures consisted of $1 \mu$ template DNA, $12.5 \mu 1$ DreamTaq PCR Master Mix (Thermo Fisher Scientific, Waltham, USA), 0.5 $\mu \mathrm{l}$ of each $20 \mathrm{pmol} / 1$ primer and $10.5 \mu \mathrm{lddH_{2 }}$. For degraded material, $1.0 \mu 1 \mathrm{MgCl}_{2}(25 \mathrm{mM})$ (Thermo Fisher Scientific, Waltham, USA) and $0.5 \mu$ dimethyl sulfoxide (DMSO) (ITW Reagents Division, Glenview, USA) were added as needed at the expense of $\mathrm{ddH}_{2} \mathrm{O}$. The PCR program for COI included a 15 min first denaturation stage at 
$94^{\circ} \mathrm{C}$, followed by 60 cycles of $30 \mathrm{sec}$ denaturation at $94^{\circ} \mathrm{C}, 30 \mathrm{sec}$ annealing at $44^{\circ} \mathrm{C}$ and $30 \mathrm{sec}$ of synthesis at $72^{\circ} \mathrm{C}$, capped by a $10 \mathrm{~min}$ final synthesis stage at $72^{\circ} \mathrm{C}$. The PCR program for amplifying the Wolbachia wsp gene was set up according to Shaikevich et al. (2019b).

PCR products were checked for positive signals by electrophoresis on a $1.6 \%$ agarose gel infused with $3.8 \mu 1$ of ethidium bromide, run for $1 \mathrm{~h}$ at $120 \mathrm{~V}$ and $70 \mathrm{~mA}$. Six $\mu$ l of each sample were mixed with $1 \mu \mathrm{l}$ of DNA Gel Loading Dye (6X) (Thermo Fisher Scientific, Waltham, USA) before it was added to the gel. GeneRuler 100 bp DNA Ladder, ready-to-use (Thermo Fisher Scientific, Waltham, USA) was used as a reference. Successfully amplified PCR products were sequenced at the Institute of Genomics Core Facility using Sanger sequencing (University of Tartu, Tartu, Estonia). Forward and reverse nucleotide strands were combined into consensus sequences and cleaned in BioEdit version 7.2.6.1 (Hall 1999). Resulting barcodes were checked against the information stored at GenBank (National Institutes of Health, Bethesda, USA) using both the US National Library of Medicine nucleotide BLAST tool (National Institutes of Health, Bethesda, USA) and the Barcode of Life Data (BOLD) Systems workbench developed by Ratnasingham \& Hebert (2007). The partial COI sequences of 49 voucher specimens are deposited in GenBank. The GenBank accession numbers for the species are provided for below.

Data availability. The mosquito count data generated during this research can be found online at FigShare (DOI: $10.6084 / \mathrm{m} 9$. figshare.16817395) or obtained from the corresponding author.

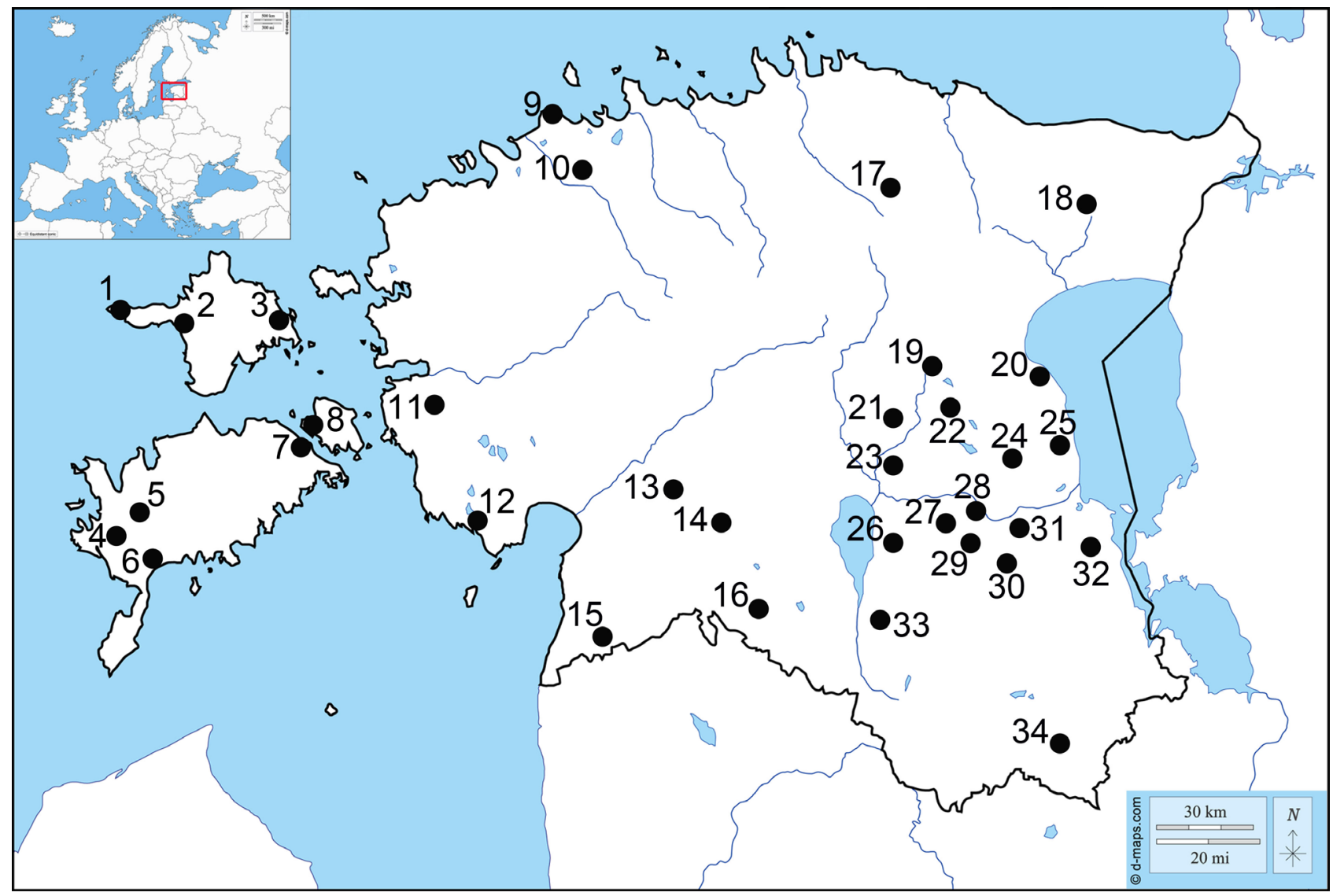

FIGURE 1. Sampling localities in Estonia: 1-Kalana, 2-Vanajõe, 3-Kerema, 4-Viidumäe, 5-Karujärve, 6-Mändjala, 7-Orissaare, 8-Igaküla, 9-Muraste, 10-Üksnurme, 11-Lihula, 12-Tõstamaa, 13-Jõesuu, 14-Punaküla, 15-Nigula NR, 16-Viivre, 17-Lasila, 18-Mäetaguse, 19-Kibuvitsa, 20-Omedu, 21-Kursi, 22-Luua, 23-Laeva, 24-Undi, 25Kolkja, 26-Maiorg, 27-Külitse, 28-Tartu, 29-Pargi, 30-Hurda, 31-Melliste, 32-Järvselja, 33-Puka, 34-Leoski. Base maps of Europe and Estonia: (C) 2007-2021 https://d-maps.com (accessed on 11 August 2021).

\section{Results}

General results. The updated checklist includes 34 species based on material collected in Estonia from 2008 to 2020 , information provided previously by Kirik et al. $(2020,2021)$ and historical records and studies from neighbor- 
ing countries. More specifically, the newly collected material included in this study consists of 24,344 adult mosquitoes ( $94.2 \%$ female), which by themselves helped confirm the presence of 27 species. Most of these mosquitoes were identified based on their morphological characteristics, but some were also submitted for genetic identification based on mitochondrial COI sequences. All mosquitoes that were collected belong to one or other of five genera: Aedes, Anopheles, Coquillettidia, Culex and Culiseta. In the following checklist, information on mosquito species in Estonia is summarized and annotated with brief comments. Regrettably, the historical material underlying the first checklist compiled by Remm (1957) no longer exists; thus, seven species not encountered during the recent collections, are included based on only literature sources.

\section{Annotated checklist}

\section{Genus Aedes Meigen, 1818}

\section{Aedes (Aedes) cinereus Meigen, 1818}

(Fig. 2A)

Published sources: Remm (1957: 156), Burtin (2014: 33), Khalin et al. (2020: 61), Kirik et al. (2021: 11).

Voucher material: 1 , , Tartu ( $58^{\circ} 21^{\prime} 26^{\prime \prime}$ N, $26^{\circ} 42^{\prime} 60^{\prime \prime}$ E), 14.VI.2017, T. Kesküla leg., H. Kirik det., sweep

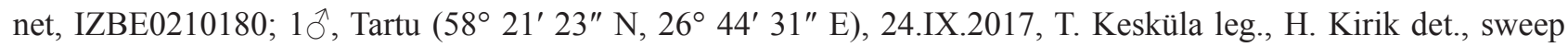

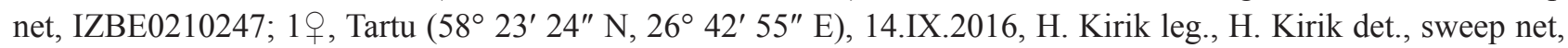
IZBE0210181, GenBank: OK465139.

Comment: 1,436 mosquitoes ( $5.9 \%$ of all specimens collected) were identified as Ae. cinereus. This species is abundant in Estonia and can be found almost everywhere from June to September. Also, Ae. cinereus can be numerous at times, especially towards the end of the summer, based on the data of the present study. It should be noted that adult females are difficult to differentiate from the closely related Ae. geminus based on morphology alone; thus, specimens of Ae. geminus could also be among the specimens of Ae. cinereus collected during the study.

\section{Aedes (Aedimorphus) vexans (Meigen, 1830)}

(Fig. 2B)

Published sources: Remm (1957: 156), Burtin (2014: 34), Lilja et al. (2018: 283), Kirik et al. (2021: 11).

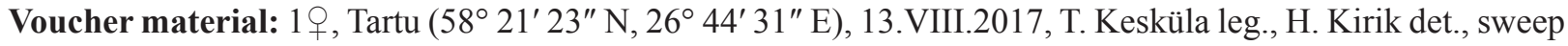
net, IZBE0210182, GenBank: OK465140; 1 , , Tartu (58 $22^{\circ} 17^{\prime \prime}$ N, $26^{\circ} 41^{\prime} 58^{\prime \prime}$ E), 21.VIII.2017, H. Kirik leg., H.

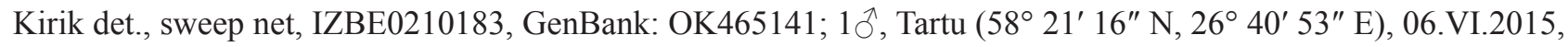
T. Kesküla leg., O. Kurina det., sweep net, IZBE0210184.

Comment: 366 mosquitoes (1.5\% of all specimens collected) were identified as Ae. vexans. This species was infrequently collected, but specimens could be found throughout the warm season, with a peak of activity in August. However, Ae. vexans has been found to emerge in large numbers after floods (Schäfer \& Lundström 2009), so their low numbers in this study could be due to sampling bias.

\section{Aedes (Ochlerotatus) annulipes (Meigen, 1830)}

(Fig. 2C)

Published sources: Remm (1957: 154), Burtin (2014: 43), Kirik et al. (2021: 11, as part of the Aedes (Ochlerotatus) annulipes group).

Voucher material: 1 , , Mändjala ( $58^{\circ} 12^{\prime} 56^{\prime \prime} \mathrm{N}, 22^{\circ} 19^{\prime} 56^{\prime \prime}$ E), 16.VI.2015, L. Tummeleht leg., H. Kirik

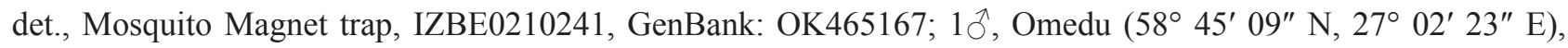
06.VI.2015, O. Kurina leg., O. Kurina det., sweep net, IZBE021218.

Comment: Aedes annulipes belongs to the Ae. annulipes group, along with Ae. cantans (Meigen, 1818), Ae. 
cyprius Ludlow, 1920, Ae. euedes Howard, Dyar \& Knab, 1913, Ae. excrucians (Walker, 1956), Ae. flavescens (Müller, 1764), Ae. riparius Dyar \& Knab, 1907, etc. (Becker et al. 2020). Aedes annulipes can be morphologically distinguished from others species of the group, but this can be difficult when it comes to adult females. This is because of the variability in their morphological traits as well as inconclusive DNA evidence, making species identification time and resource extensive. For the purposes of this study, mosquitoes with morphology similar to Ae. annulipes were designated as specimens of the Ae. annulipes group. In total, 2,091 individuals ( $8.6 \%$ of all specimens collected) were identified as simply belonging to the group. These mosquitoes were active from May to October, but were most numerous in June. Two specimens, which corresponded well to both the morphological description of Ae. annulipes and the partial COI sequences found in online databases, were chosen as the local voucher specimens.

\section{Aedes (Ochlerotatus) cantans (Meigen, 1818)}

(Fig. 2C)

Published sources: Remm (1957: 152, as Aëdes maculatus Meigen, 1804), Burtin (2014: 43), Kirik et al. (2021: 11, under the Aedes (Ochlerotatus) annulipes group).

Voucher material: 19 , Tartu ( $58^{\circ} 22^{\prime} 17^{\prime \prime}$ N, $26^{\circ} 41^{\prime} 58^{\prime \prime}$ E), 06.VI.2017, H. Kirik leg., H. Kirik det., sweep

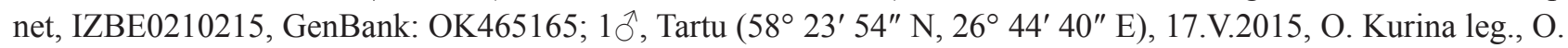

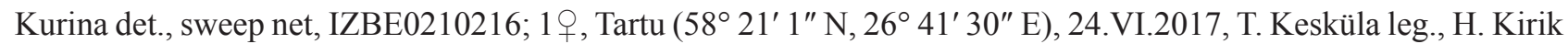
det., sweep net, IZBE0210217, GenBank: OK465166.

Comment: Aedes cantans belongs to the Ae. annulipes group. The species of this group can be distinguished based on morphological characteristics, but due to the variability of some traits, as well as inconclusive results of DNA barcoding, mosquitoes similar to Ae. cantans were designated as specimens of the Ae. annulipes group. In all, 2,091 mosquitoes ( $8.6 \%$ of all specimens collected) were as belonging to the Ae. annulipes group. These individuals were found throughout the warm months, but were most numerous in June. Voucher material was chosen from among specimens that best corresponded to the morphological traits of Ae. cantans and matched well with reliable DNA sequences in online databases.

\section{Aedes (Ochlerotatus) caspius (Pallas, 1771)}

(Fig. 2D)

Published source:_Remm (1957: 152).

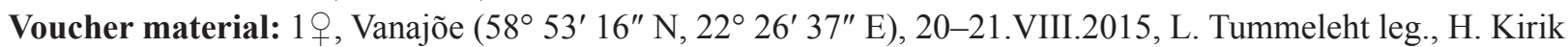

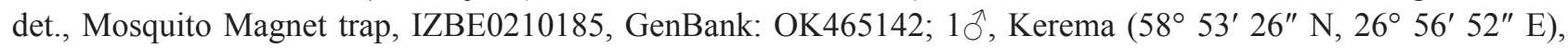

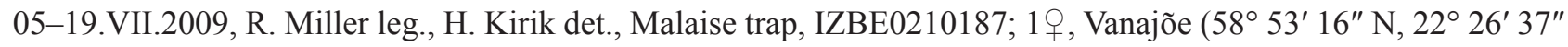
E), 21-22.VIII.2015, L. Tummeleht leg., H. Kirik det., Mosquito Magnet trap, IZBE0210186.

Comment: 206 mosquitoes ( $0.9 \%$ of all specimens collected) were identified as Ae. caspius. Aedes caspius is a halophilic species mainly found in Estonia near the brackish water of the Baltic Sea. These mosquitoes are common and at times numerous near the coastline, but are rarely found further inland. Thus, their relatively low numbers collected in this study is due to collection bias. Aedes caspius appears to be active throughout summer.

\section{Aedes (Ochlerotatus) cataphylla Dyar, 1916}

(Fig. 2E)

Published sources: Remm (1957: 154), Khalin et al. (2020: 66), Kirik et al. (2021: 11).

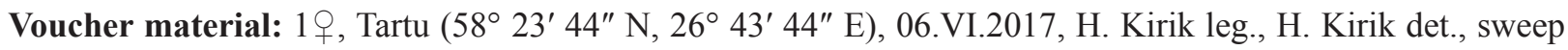
net, IZBE0210188, GenBank: OK465143; 1우, Tartu (58 20' 52" N, 26 41' 37" E), 14.VI.2017, T. Kesküla leg., H.

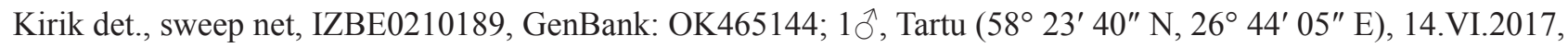
H. Kirik leg., H. Kirik det., sweep net, IZBE0210244.

Comment: 3,951 mosquitoes (16.2\% of all specimens collected) were identified as Ae. cataphylla, making it 
the third most common mosquito species in Estonia. This species is abundant almost everywhere in the country and can be numerous at times. As is typical for a spring-time species, Ae. cataphylla are most active in May, but some specimens can be found until September.

\section{Aedes (Ochlerotatus) communis (de Geer, 1776)}

(Fig. 2F)

Published sources: Remm (1957: 155), Burtin (2014: 44), Kirik et al. (2021: 11).

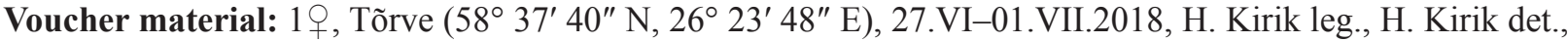
Mosquito Magnet trap, IZBE0210190, GenBank: OK465145; 1 우, Tartu (58 23' 40" N, 26 44' 05" E), 06.VI.2017,

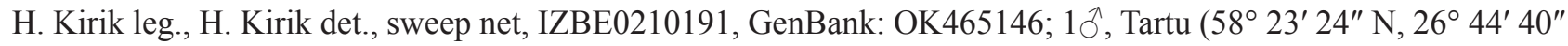
E), 17.V.2015, O. Kurina leg., O. Kurina det., sweep net, IZBE0210192.

Comment: 7,316 mosquitoes (30.1\% of all specimens collected) were identified as Ae. communis, making it the dominant species in Estonia. Aedes communis can be found everywhere in the country. It is especially numerous during May and June, but individuals can be found until October. Importantly, there appears to be two distinct mitochondrial lineages in the area, which can make DNA barcoding difficult, as some $C O I$ sequences appear to be very similar to the North American Ae. tahoensis (Dyar, 1916) (Kirik et al. 2020).

\section{Aedes (Ochlerotatus) cyprius Ludlow, 1920}

(Fig. 2G)

Published source: Remm (1957: 153).

Voucher material: 1 \% , Lasila (59 $16^{\prime} 47^{\prime \prime}$ N, $26^{\circ} 13^{\prime} 24^{\prime \prime}$ E), 31.V.2016, M. Kruus leg., H. Kirik det., Malaise trap, IZBE0210193, GenBank: OK465147; 1 9 , Lasila (59 16' 47" N, 26 13' 24" E), 31.V.2016, M. Kruus leg., H. Kirik det., Malaise trap, IZBE0210194, GenBank: OK465148.

Comment: Four mosquitoes were identified as Ae. cyprius. It was very rare among the mosquitoes collected during this study, but it can be found at the beginning of the warm season in May and June. The only individuals collected in the country from 2008 to 2020 were caught in northern Estonia. The low numbers captured could also be due to collection bias.

\section{Aedes (Ochlerotatus) diantaeus Howard, Dyar \& Knab, 1913}

(Fig. 2H)

Published sources: Remm (1957: 154), Burtin (2014: 45), Kirik et al. (2021: 11).

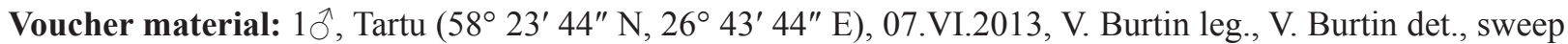
net, IZBE0210010.

Comment: In this study, only one mosquito was identified as Ae. diantaeus. This single specimen was collected in southeastern Estonia at the beginning of June. More research is needed to better understand the abundance of this species in the country.

\section{Aedes (Ochlerotatus) dorsalis (Meigen, 1830)}

(Fig. 3A)

Published source: Remm (1957: 152).

Voucher material: None.

Comment: One male and four females of Ae. dorsalis have been reported from Estonia (Remm 1957). However, the specimens have not been preserved and cannot be verified. No specimens were found during the present study. Aedes dorsalis has been reported from Lithuania (Pakalniškis et al. 2000), Latvia (Spungis 2000), provinces 
adjacent to Estonia in northwestern Russia (Khalin \& Aibulatov 2020), Finland (Culverwell 2018; Culverwell et al. 2021) and Sweden (Lundström et al. 2013). Therefore, this species is likely to be present in Estonia as well. The absence of specimens in collections made during this study could be due to insufficient trapping, as well as collection bias, as Ae. dorsalis is halophilic and has been known to be associated with floods (Becker et al. 2020).

\section{Aedes (Ochlerotatus) excrucians (Walker, 1856)}

(Fig. 3B)

Published sources: Remm (1957: 154), Burtin (2014: 46), Kirik et al. (2021: 11).

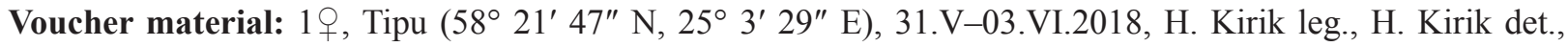

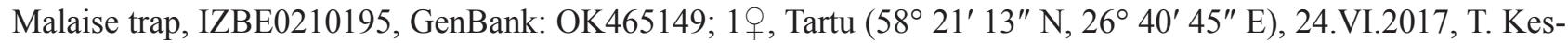

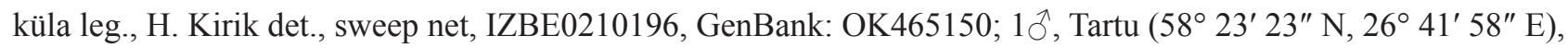
30.V.2015, O. Kurina leg., O. Kurina det., sweep net, IZBE0210197.

Comment: 193 mosquitoes ( $0.8 \%$ of all collected specimens collected) were identified as Ae. excrucians. The species appears to be uncommon in the country based on this study, but individuals can be found from May to October, although the peak of their activity seems to be in June.

\section{Aedes (Ochlerotatus) flavescens (Müller, 1764)}

(Fig. 3C)

Published sources: Remm (1957: 153), Burtin (2014: 46), Kirik et al. (2021: 11).

Voucher material: 1 , , Undi ( $58^{\circ} 29^{\prime} 44^{\prime \prime} \mathrm{N}, 26^{\circ} 54^{\prime} 00^{\prime \prime}$ E), 15-16.VIII.08.2016, L. Tummeleht leg., H. Kirik

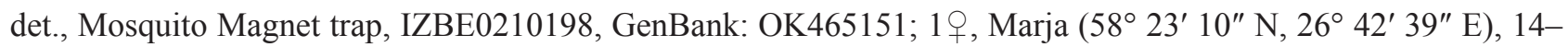
15.VI.2016, O. Kurina leg., H. Kirik det., Mosquito Magnet trap, IZBE0210199, GenBank: OK465152; 1 , Marja (58 $23^{\prime} 10^{\prime \prime} \mathrm{N}, 26^{\circ} 42^{\prime} 39^{\prime \prime}$ E), 19-21.VI.2015, O. Kurina leg., H. Kirik det., Mosquito Magnet trap, IZBE0210200, GenBank: OK465153.

Comment: 77 mosquitoes ( $0.3 \%$ of all specimens collected) were identified as Ae. flavescens. This species seems to be rare in Estonia, but specimens can be found throughout the warm season, from May to October. It is slightly more numerous in May.

\section{Aedes (Ochlerotatus) hexodontus Dyar, 1916}

(Fig. 3D)

\section{Published sources: None.}

Voucher material: 1 , , Tõrve $\left(58^{\circ} 35^{\prime} 56^{\prime \prime} \mathrm{N}, 26^{\circ} 22^{\prime} 20^{\prime \prime}\right.$ E), 27.VI-01.VII.2018, H. Kirik leg., H. Kirik det., Mosquito Magnet trap, IZBE0210201, GenBank: OK465154; 1 \% , Undi (58 29' 44" N, $26^{\circ} 54^{\prime} 00^{\prime \prime}$ E), $15-$ 16.V.2016, L. Tummeleht leg., H. Kirik det., Mosquito Magnet trap, IZBE0210202, GenBank: OK465155; 1 , Undi (58 $29^{\prime} 44^{\prime \prime} \mathrm{N}, 26^{\circ} 54^{\prime}$ 00" E), 22-23.V.2015, L. Tummeleht leg., H. Kirik det., Mosquito Magnet trap, IZBE0210203, GenBank: OK465156.

Comment: 35 mosquitoes $(0.1 \%$ of all specimens collected) were identified as Ae. hexodontus. This species appears to be relatively rare in Estonia and from 2008 to 2020 it was only collected in May and June.

\section{Aedes (Ochlerotatus) intrudens Dyar, 1919}

(Fig. 3E)

Published sources: Remm (1957: 156), Burtin (2014: 47), Kirik et al. (2021: 11).

Voucher material: 19 , Tartu (58 $21^{\prime} 26^{\prime \prime}$ N, $26^{\circ} 42^{\prime} 60^{\prime \prime}$ E), 04.VI.2017, T. Kesküla leg., H. Kirik det., sweep net, IZBE0210204, GenBank: OK465157; 1 , Viivre (58 04' 52" N, 25 31' 26" E), 18-19.VI.2016, H. Kirik leg., 
H. Kirik det., Mosquito Magnet trap, IZBE0210205, GenBank: OK465158; $10^{\prime}$, Tartu (58 $23^{\prime} 24^{\prime \prime}$ N, $26^{\circ} 44^{\prime} 40^{\prime \prime}$ E), 17.V.2015, O. Kurina leg., O. Kurina det., sweep net, IZBE0210206.

Comment: 189 mosquitoes ( $0.8 \%$ of all specimens collected) were identified as Ae. intrudens. This species was uncommon in Estonia during the fieldwork of this study. Aedes intrudens appears to be active from May to July, but it is more numerous in May.

\section{Aedes (Ochlerotatus) leucomelas (Meigen, 1804)}

(Fig. 3F)

Published sources: Remm (1957: 154), Kirik et al. (2021: 11).

Voucher material: 1 q , Tõrve (58 37' 32" N, 26² 23' 24" E), 26-29.V.2018, H. Kirik leg., H. Kirik det., Mos-

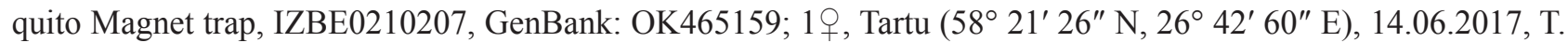

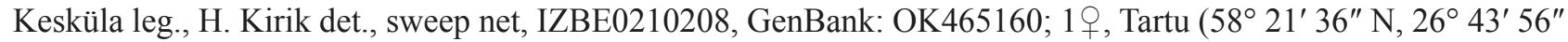
E), 19.VI.2017, T. Kesküla leg., H. Kirik det., sweep net, IZBE0210209.

Comment: 211 mosquitoes ( $0.9 \%$ of all specimens collected) were identified as Ae. leucomelas. This species seems to be uncommon in Estonia, much less common than the closely related Ae. cataphylla. Mosquitoes identified as Ae. leucomelas were most numerous in May, but some individuals were found until October during this study.

\section{Aedes (Ochlerotatus) nigrinus (Eckstein, 1918)}

(Fig. 3G)

Published sources: Remm (1957: 155), Burtin (2014: 48).

Voucher material: None.

Comment: Three males and 23 females of Ae. nigrinus were previously reported from Estonia (Remm 1957), but the specimens have not been preserved. No specimens were collected during this study. However, Ae. nigrinus has also been recorded in Lithuania (Pakalniškis et al. 2000), provinces in northwestern Russia adjacent to Estonia (Khalin \& Aibulatov 2020), Finland (Harbach et al. 2017; Culverwell et al., 2021) and Sweden (Lundström et al. 2013). Therefore, this species is likely to be present in Estonia as well.

\section{Aedes (Ochlerotatus) punctor (Kirby, 1837)}

(Fig. 3H)

Published sources: Remm (1597: 155), Burtin (2014: 48), Kirik et al. (2021: 11).

Voucher material: 1 , , Tartu (58 $22^{\prime} 52^{\prime \prime}$ N, $26^{\circ} 42^{\prime} 49^{\prime \prime}$ E), 06.VI.2017. H. Kirik leg., H. Kirik det., sweep net, IZBE0210210, GenBank: OK465161; 1 \%, Tartu (58 22' 52" N, $26^{\circ} 42^{\prime} 49^{\prime \prime}$ E), 19.VI.2017, H. Kirik leg., H.

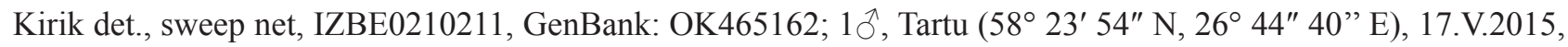
O. Kurina leg., O. Kurina det., sweep net, IZBE0210212.

Comment: 4,594 mosquitoes (18.9\% of all specimens collected) were grouped as Ae. punctor/punctodes Dyar, 1922, although males were identified as Ae. punctor. Aedes punctor is known to be more common than Ae. punctodes (Culverwell et al., 2021), but further DNA analysis or larval collections are required to make definitive conclusions about the presence of Ae. punctodes in Estonia. The two females of Ae. punctor/punctodes chosen as voucher specimens were identified as Ae. punctor by DNA barcoding. These mosquitoes were especially numerous in May during this study, but some individuals were found until October.

\section{Aedes (Ochlerotatus) riparius Dyar \& Knab, 1907}

(Fig. 4B)

Published source: Remm (1957: 153). 
Voucher material: None.

Comment: Aedes riparius belongs to the Ae. annulipes group and can be difficult to identify. A specimen corresponding to morphologically to Ae. riparius was found during this study, but DNA barcoding identified it as $A e$. annulipes/cantans. One male, four females and one larva of Ae. riparius have previously been reported from Estonia (Remm 1957), but these individuals have not been preserved and their identification cannot be verified. Aedes riparius has been found in Lithuania (Pakalniškis et al. 2000), Latvia (Spungis 2000), provinces in Northwestern Russia adjacent to Estonia (Khalin \& Aibulatov 2020), Finland (Culverwell 2018; Culverwell et al. 2021) and Sweden (Lundström et al. 2013); consequently, Ae. riparius is likely present in Estonia as well.

19. Aedes (Ochlerotatus) sticticus (Meigen, 1838)

(Fig. 4A)

Published source: Kirik et al. (2021: 11).

Voucher material: 1 , , Külitse ( $58^{\circ} 20^{\prime} 5^{\prime \prime}$ N, $26^{\circ} 35^{\prime} 57^{\prime \prime}$ E), 01-03.VIII.2020, V. Oborina leg., H. Kirik det.,

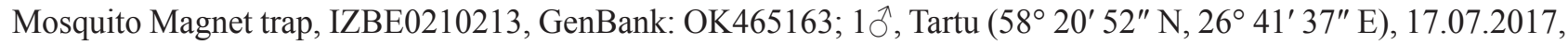

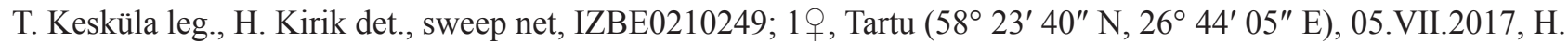
Kirik leg., H. Kirik det., sweep net, IZBE0210214, GenBank: OK465164.

Comment: 231 mosquitoes (1.0\% of all specimens collected) were identified as Ae. sticticus. This species appears to be uncommon in the country based on the current collections. However, the abundance of Ae. sticticus has been found to depend on floods, and they can be numerous at certain times (Schäfer \& Lundström 2009). Their relatively low numbers in this study could be due to collection bias. Interestingly, Ae. sticticus was encountered more often in August, which is unusual compared to most Aedes species in the area. Overall, some Ae. sticticus can be found in Estonia throughout the summer, from June to September.

\section{Genus Anopheles Meigen, 1818}

\section{Anopheles (Anopheles) algeriensis Theobald, 1903}

(Fig. 4C)

Published source: Remm (1957: 150).

Voucher material: None.

Comment: Nine An. algeriensis females have been previously reported from Estonia, but these specimens have not been preserved and cannot be verified. No new specimens were found during this study. Also, Sweden is the closest country to Estonia where An. algeriensis has been collected (Lundström et al. 2013). In fact, this species appears to be most common in Mediterranean and Balkan countries (Scholte et al. 2011).

\section{Anopheles (Anopheles) claviger (Meigen, 1804)}

(Fig. 4D)

Published sources: Remm (1957: 150, as Anopheles bifurcatus Linnaeus, 1758), Burtin (2014: 35), Kirik et al. (2021: 11).

Voucher material: 1 , Ülenurme $\left(58^{\circ} 19^{\prime} 3^{\prime \prime}\right.$ N, $26^{\circ} 43^{\prime} 23^{\prime \prime}$ E), 14-17.VIII.2020, H. Kirik leg., H. Kirik

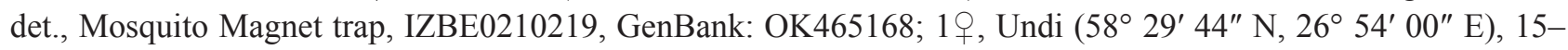
16.VIII.2016, L. Tummeleht leg., H. Kirik det., Mosquito Magnet trap, IZBE0210220, GenBank: OK465169; $1 \delta^{\text {, }}$ Tartu (58 23' 24" N, 26 42' 55" E), 03.IX.2013, V. Burtin leg., V. Burtin det., sweep net, IZBE0210007.

Comment: 1,038 mosquitoes ( $4.3 \%$ of all specimens collected) were identified as An. claviger. This species is abundant in Estonia, especially during August, but some individuals can be found from May to October. Anopheles claviger was the most common anopheline mosquito in this study. 


\section{Anopheles (Anopheles) maculipennis Meigen, 1818 s.s.}

(Fig. 4E)

Published sources: Remm (1957: 151), Burtin (2014: 36, as An. maculipennis s.l.), Kirik et al. (2021: 11, part of the An. maculipennis complex).

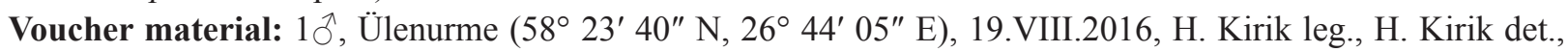
sweep net, IZBE0210243, GenBank: OK465173.

Comment: Anopheles maculipennis is the nominotypical species of the An. maculipennis complex. Three mosquitoes were identified as An. maculipennis s.s among of 20 specimens of the An. maculipennis complex that were subjected to DNA barcoding. These results indicate that An. maculipennis is likely to be quite uncommon in the country, as only 215 mosquitoes ( $0.9 \%$ of all collected specimens collected) were identified as belonging to the $A n$. maculipennis complex, and presumably An. maculipennis makes up a small portion of these individuals. The true abundance of the An. maculipennis complex is likely to have been underestimated in this study due to collection bias.

\section{Anopheles (Anopheles) messeae Falleroni, 1926}

(Fig. 4E)

Published source: Kirik et al. (2020: 5).

Voucher material: 1 , , Punaküla $\left(58^{\circ} 20^{\prime} 9^{\prime \prime}\right.$ N, $25^{\circ} 20^{\prime} 4^{\prime \prime}$ E), 31.V.-03.VI.2018, H. Kirik leg., H. Kirik det.,

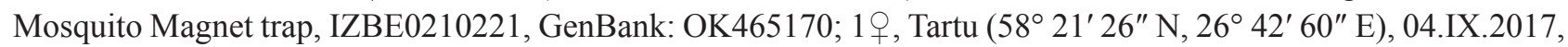
T. Kesküla leg., H. Kirik det., sweep net, IZBE0210222, GenBank: OK465171; 1 \%, Tartu $\left(58^{\circ} 21^{\prime} 13^{\prime \prime}\right.$ N, $26^{\circ} 40^{\prime}$ 45” E), 17.IX.2017, T. Kesküla leg., H. Kirik det., sweep net, IZBE0210223, GenBank: OK465172.

Comment: Anopheles messeae belongs to the An. maculipennis complex. Based on COI sequences, 17 mosquitoes among 20 specimens of the complex subjected to genetic analyses were identified as An. messeae or An. daciae Linton, Nicolescu \& Harbach, 2004 (in Nicolescu et al. 2004). This indicates that An. messeaeldaciae most likely make up the majority of the 215 ( $0.9 \%$ of all specimens collected) specimens of the complex collected in this study. Anopheles messeae and An. daciae are difficult to distinguish based on COI sequences at this time, but the ribosomal internal transcribed spacer 2 (ITS2) region of one Estonian An. messeae specimen was sequenced in a previous study (Kirik et al. 2020). All in all, individuals belonging to the An. maculipennis complex could be found from May to October, but were more numerous in August. The abundance of mosquitoes of the complex may be underestimated in this study due to collection bias.

\section{Anopheles (Anopheles) plumbeus Stephens, 1828}

(Fig. 4F)

Published source: Remm (1957: 150).

Voucher material: None.

Comment: There are historical records of four An. plumbeus females collected from Estonia (Remm 1957). No specimens were identified during this study, but this may be because of collection bias. Anopheles plumbeus has also been reported from Lithuania (Pakalniškis et al. 2000) and Sweden (Lundström et al. 2013), but not from other countries neighboring Estonia.

\section{Genus Coquillettidia Dyar, 1904}

\section{Coquillettidia (Coquillettidia) richiardii (Ficalbi, 1889)}

(Fig. 4G)

Published sources: Remm (1957: 152, as Mansonia richiardii), Burtin (2014: 38), Kirik et al. (2021: 11). 
Voucher material: 1 , , Undi ( $58^{\circ} 29^{\prime} 44^{\prime \prime} \mathrm{N}, 26^{\circ} 54^{\prime} 00^{\prime \prime}$ E), 16-17.VIII.2015, L. Tummeleht leg., H. Kirik

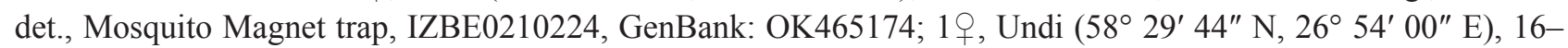
17.VIII.2015, L. Tummeleht leg., H. Kirik det., Mosquito Magnet trap, IZBE0210225, GenBank: OK465175; $1 \delta^{\Uparrow}$, Tartu (58 23' 20" N, 26 42' 52" E), 31.VII.2017, H. Kirik leg., H. Kirik det., sweep net, IZBE0210251.

Comment: 787 mosquitoes (3.2\% of all specimens collected) were identified as Cq. richiardii. This species is common in the country and specimens have been found from June to October, with a peak of activity in July.

\section{Genus Culex Linnaeus, 1758}

\section{Culex (Culex) pipiens Linnaeus, 1758}

(Fig. 4H)

Published sources: Remm (1957: 157), Burtin (2014: 39), Kirik et al. (2021: 11, as Cx. (Cux.) pipiens/torrentium).

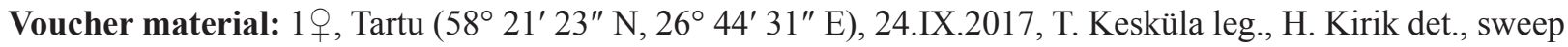

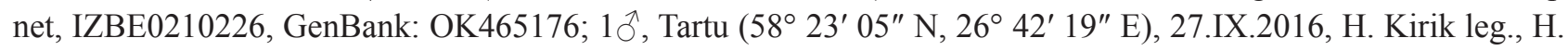

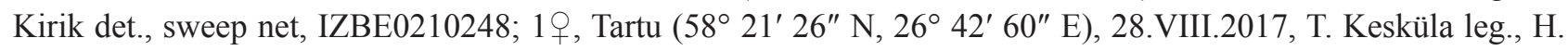
Kirik det., sweep net, IZBE0210227, GenBank: OK465177.

Comment: Adults of $C x$. pipiens are difficult to distinguish from $C x$. torrentium by morphological characteristics alone. However, when 12 Cx. pipiens/torrentium females were subjected to DNA barcoding, five (41.7\%) were identified as $C x$. pipiens. In 2013, 64 (48.5\%) male mosquitoes were identified as $C x$. pipiens compared to 68 (51.5\%) determined to be $C x$. torrentium. In 2017. however, $84(60.9 \%)$ males were identified as $C x$. pipiens and only 54 (39.1\%) were identified as $C x$. torrentium. Based on this information, $C x$. pipiens and $C x$. torrentium could be present in relatively similar numbers in Estonia. It is possible that the true relative abundance of $C x$. pipiens is underestimated in this study due to collection bias. Mosquitoes identified as $C x$. pipiens/torrentium were most numerous in September. Also, Cx. pipiens specimens in Estonia were found to be infected with the intercellular symbiont Wolbachia pipientis, which agrees with the published literature (Bergman \& Hesson 2021; Inácio da Silva et al. 2021). No attempts were made to identify the "molestus" biotype of $C x$. pipiens among the specimens collected during the study.

\section{Culex (Culex) torrentium Martini, 1925}

(Fig. 4H)

Published sources: Remm (1057: 157, as Culex exilis Dyar, 1924), Burtin (2014: 40), Kirik et al. (2021: 11, as Cx. (Cux.) pipiens/torrentium).

Voucher material: 1 , , Tartu $\left(58^{\circ} 22^{\prime} 17^{\prime \prime}\right.$ N, $26^{\circ} 41^{\prime} 58^{\prime \prime}$ E), 27.IX.2016, H. Kirik leg., H. Kirik det., sweep

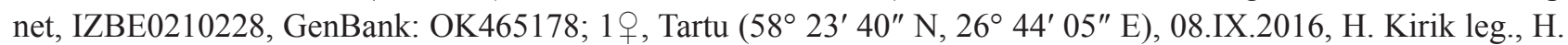

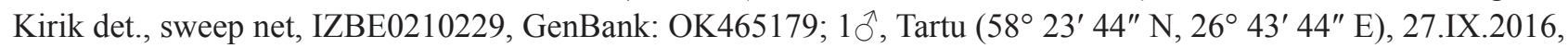
H. Kirik leg., H. Kirik det., sweep net, IZBE0210245.

Comment: The adult females of $C x$. torrentium are difficult to distinguish from $C x$. pipiens based on only morphological characteristics. Of 12 females subjected to DNA barcoding, seven (58.3\%) were identified as $C x$. torrentium. Adult males of the two species can be distinguished based on structures of their genitalia. In 2013, 68 (51.5\%) among 132 males were identified as $C x$. torrentium. In 2017, only 54 (39.1\%) males were determined to be Cx. torrentium compared to 84 (60.9\%) of individuals identified as Cx. pipiens. All things considered, it is reasonable to assume that $C x$. torrentium makes up about half of the 1,236 (5.1\% of all collected mosquitoes collected) identified as $C x$. pipiens/torrentium during in this study. However, the true relative abundance of these mosquitoes may have been underestimated in this study due to collection bias. Culex torrentium and Cx. pipiens are most active at the end of summer, when they become dominant. Seven $C x$. torrentium caught in Estonia were analyzed for Wolbachia pipientis using the wsp gene for detection. The results were negative, which is in line with the findings of Bergman \& Hesson (2021). 

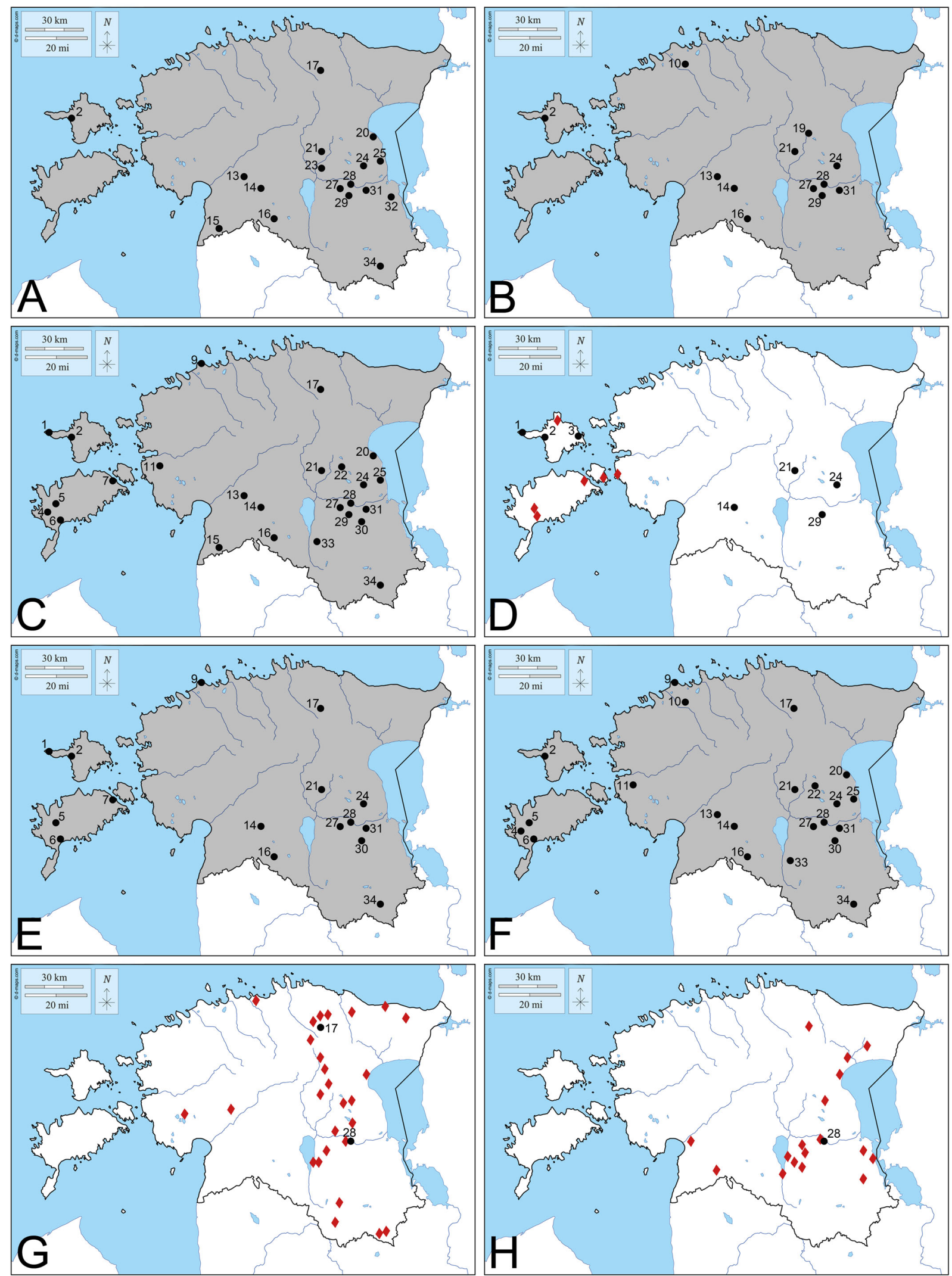

FIGURE 2. Maps showing the historic and current collection points of individual mosquito species in Estonia. A, Aedes (Aedes) cinereus; B, Aedes (Aedimorphus) vexans; C, Aedes annulipes group; D, Aedes (Ochlerotatus) caspius; E, Aedes (Ochlerotatus) cataphylla; F, Aedes (Ochlerotatus) communis; $\mathbf{G}$, Aedes (Ochlerotatus) cyprius; $\mathbf{H}$, Aedes (Ochlerotatus) diantaeus. Numbers indicate original data and correspond to on the numbers in Fig. 1. Red diamonds indicate localities collected by Remm (1955). In cases where Remm indicated the species was widely distributed in Estonia, the area is shaded in gray. 

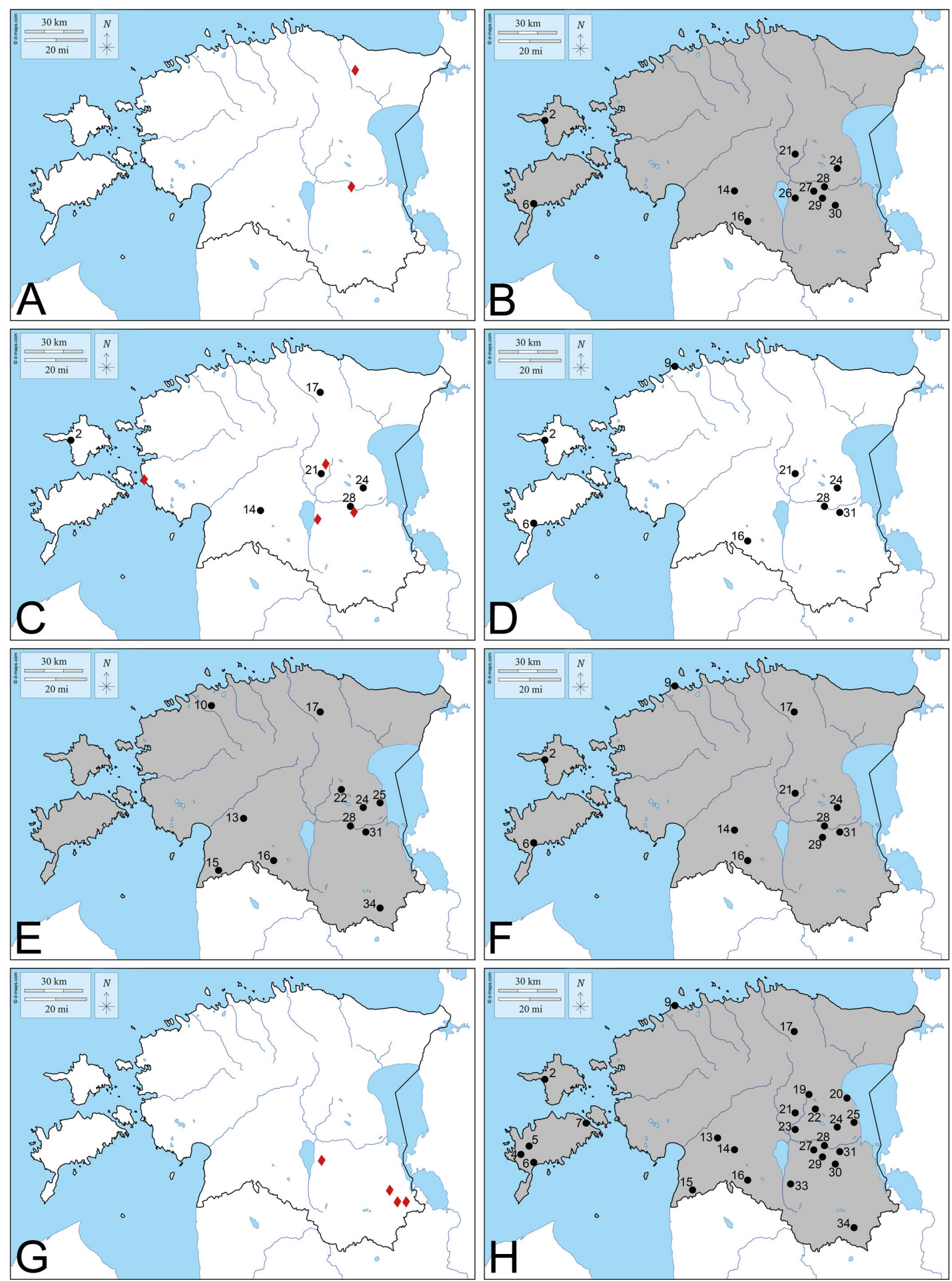

FIGURE 3. Maps showing the historic and current collection points of individual mosquito species in Estonia. A, Aedes (Ochlerotatus) dorsalis; B, Aedes (Ochlerotatus) excrucians; C, Aedes (Ochlerotatus) flavescens; D, Aedes (Ochlerotatus) hexodontus; E, Aedes (Ochlerotatus) intrudens; F, Aedes (Ochlerotatus) leucomelas; G, Aedes (Ochlerotatus) nigrinus; H, Aedes (Ochlerotatus) punctor. For details, see Fig. 2. 

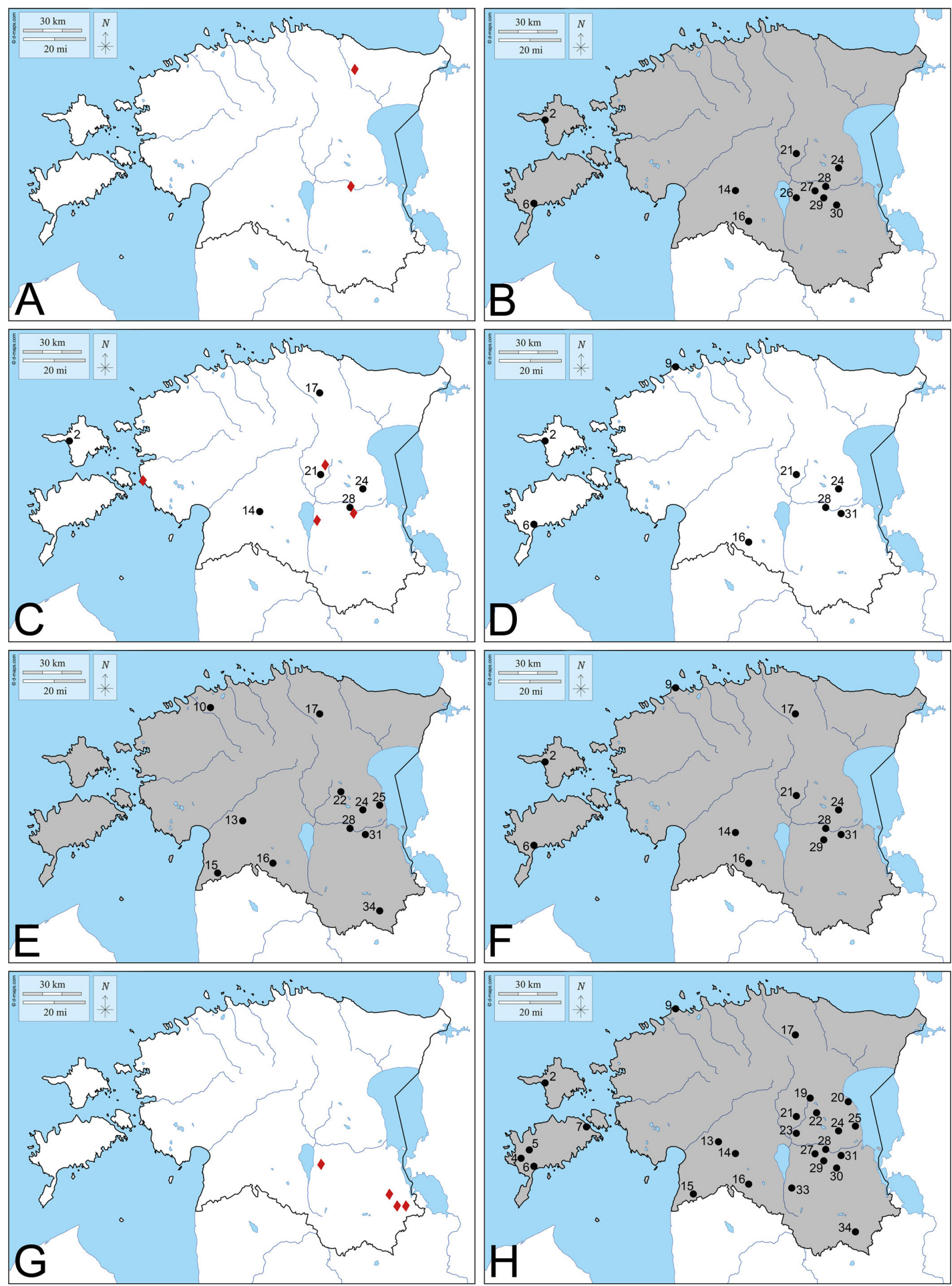

FIGURE 4. Maps showing the historic and current collection points of individual mosquito species in Estonia. A, Aedes (Ochlerotatus) sticticus; B, Aedes (Ochlerotatus) riparius; C, Anopheles (Anopheles) algeriensis; D, Anopheles (Anopheles) claviger; E, Anopheles maculipennis complex; F, Anopheles (Anopheles) plumbeus; G, Coquillettidia (Coquillettidia) richiardii; $\mathbf{H}$, Culex pipiens complex.. For details, see Fig. 2. 

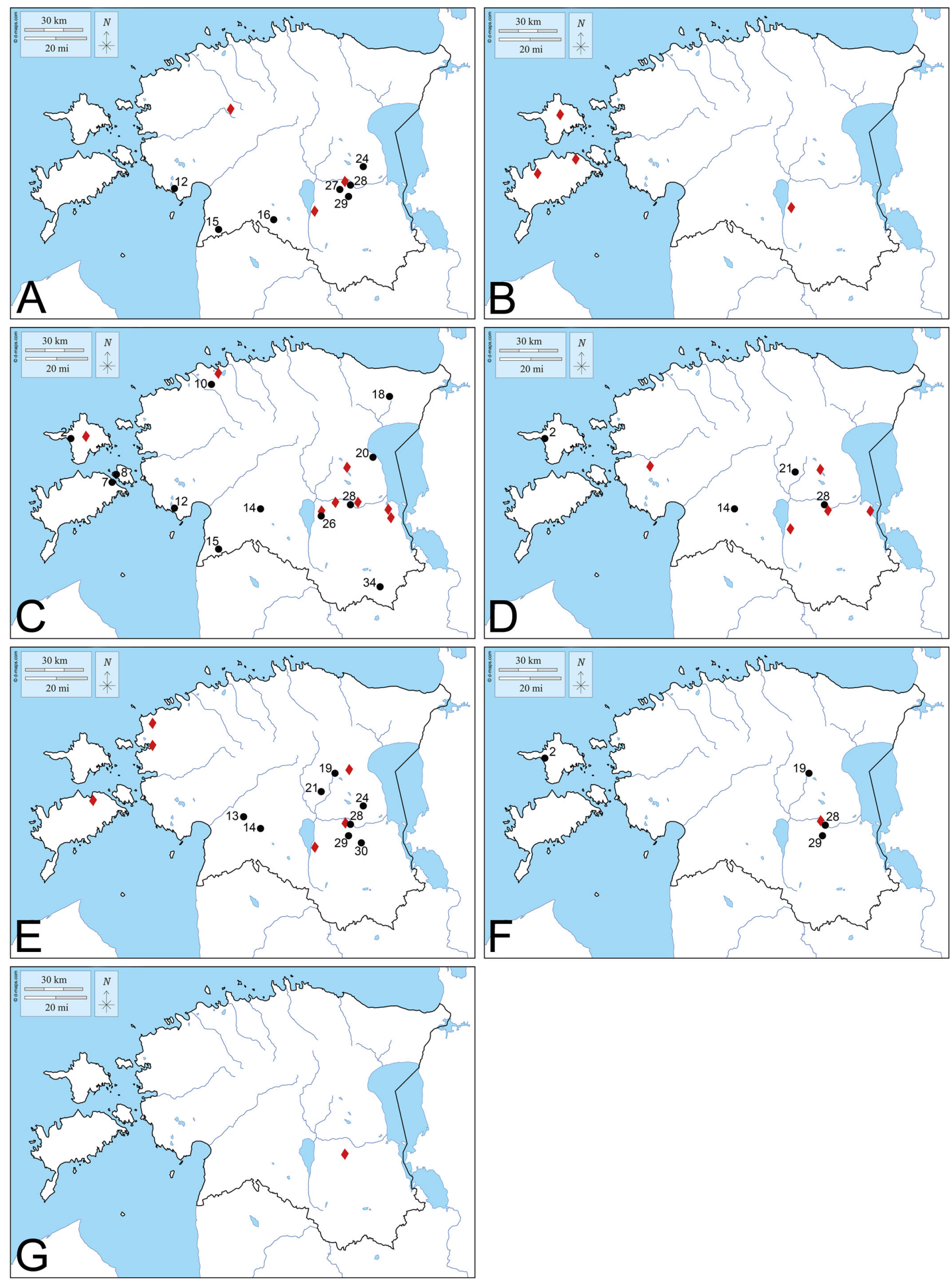

FIGURE 5. Maps showing the historic and current collection points of individual mosquito species in Estonia. A, Culex (Neoculex) territans; B, Culiseta (Culicella) fumipennis; C, Culiseta (Culicella) morsitans; D, Culiseta (Culicella) ochroptera; $\mathbf{E}$, Culiseta (Culiseta) alaskaensis; F, Culiseta (Culiseta) annulata; G, Culiseta (Culiseta) bergrothi. For details, see Fig. 2, except for data for Cs. bergrothi, which is provided according to Khalin \& Aibulatov (2020). 


\section{Culex (Neoculex) territans Walker, 1856}

(Fig. 5A)

Published sources: Remm (1957: 157, as Culex apicalis Adams, 1903), Burtin (2014: 41), Kirik et al. (2021: 11).

Voucher material: 1 , , Tartu $\left(58^{\circ} 22^{\prime} 52^{\prime \prime}\right.$ N, $26^{\circ} 42^{\prime} 49^{\prime \prime}$ E), 08.IX.2016, H. Kirik leg., H. Kirik det., sweep

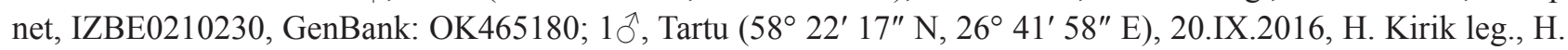
Kirik det., sweep net, IZBE0210250.

Comment: 50 mosquitoes ( $0.2 \%$ of all specimens collected) were identified as $C x$. territans, making it the least common Culex species in Estonia. Culex territans was collected from July to October. This species is likely more common than the results of this fieldwork indicate, and their very low numbers are expected to be because of collection bias.

\section{Genus Culiseta Felt, 1904}

29. Culiseta (Culicella) fumipennis (Stephens, 1825) (Fig. 5B)

Published source: Remm (1957: 152, as Theobaldia fumipennis).

Voucher material: None.

Comment: Five females of Cs. fumipennis were previously reported from Estonia (Remm 1957). No individuals were found during this study. Of countries neighboring Estonia, Cs. fumipennis has been collected in Sweden (Lundström et al. 2013) and a province in northwestern Russia adjacent to Estonia (Khalin \& Aibulatov 2020).

\section{Culiseta (Culicella) morsitans (Theobald, 1901)}

(Fig. 5C)

Published source: Remm (1957: 152, as Theobaldia morsitans).

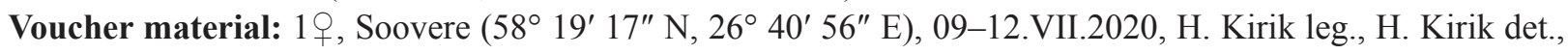

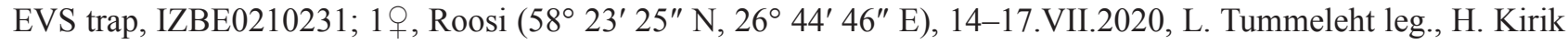

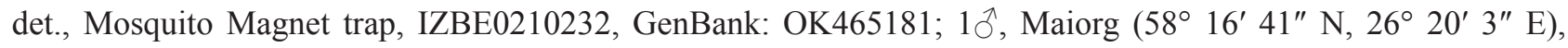
14-28.VI.2009, O. Kurina leg., H. Kirik det., Malaise trap, IZBE0210233.

Comment: 41 mosquitoes $(0.2 \%$ of all specimens collected) were identified as Cs. morsitans, making it the most commonly collected Culiseta species during this study. Culiseta morsitans was found in insect traps from June to September. The low number of individuals collected is likely due to collection bias.

\section{Culiseta (Culicella) ochroptera (Peus, 1935)}

(Fig. 5D)

Published sources: Remm (1957: 152, as Theobaldia ochroptera), Kirik et al. (2021: 11).

Voucher material: 1 , , Tipu ( $\left.58^{\circ} 21^{\prime} 44^{\prime \prime} \mathrm{N}, 25^{\circ} 3^{\prime} 44^{\prime \prime} \mathrm{E}\right), 22-26 . V I .2018$, H. Kirik leg., H. Kirik det., Mosquito Magnet trap, IZBE0210234, GenBank: OK465182; 1 9 , Tartu (58 23' 05" N, 26 42' 19" E), 14.IX.2016, H.

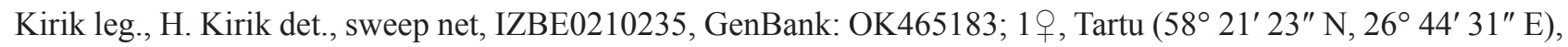
24.IX.2017, T. Kesküla leg., H. Kirik det., sweep net, IZBE0210236.

Comment: 11 mosquitoes were identified as Cs. ochroptera. These specimens were collected from August to October. The low number of individuals collected is likely to be due to sampling bias. 


\section{Culiseta (Culiseta) alaskaensis (Ludlow, 1906)}

(Fig. 5E)

Published source: Remm (1957: 151, as Theobaldia alaskaensis).

Voucher material: 1 q , Undi ( $58^{\circ} 29^{\prime} 44^{\prime \prime}$ N, $26^{\circ} 54^{\prime} 00^{\prime \prime}$ E), 21-22.IV.2015, L. Tummeleht leg., H. Kirik det., Mosquito Magnet trap, IZBE0210237, GenBank: OK465184; 1 , , Ülenurme (58 $\left.19^{\prime} 3^{\prime \prime} \mathrm{N}, 26^{\circ} 43^{\prime} 23^{\prime \prime} \mathrm{E}\right)$, 1114.VIII.2020, H. Kirik leg., H. Kirik det., Mosquito Magnet trap, IZBE0210238, GenBank: OK465185; 1 $^{\lambda}$, Kibuvitsa (58 46 3" N, 26 30' 46" E), May to October 2020, L. Laaser leg., H. Kirik det., light trap, IZBE0210242.

Comment: 37 mosquitoes ( $0.2 \%$ of all specimens collected) were identified as Cs. alaskaensis, making it the second most common Culiseta species in Estonia based on this study. Culiseta alaskaensis appears to be active from April to August. The low number of individuals collected is likely to be due to sampling bias.

\section{Culiseta (Culiseta) annulata (Schrank, 1776)}

(Fig. 5F)

Published sources: Remm (1957: 151, as Theobaldia annulata), Burtin (2014: 42), Kirik et al. (2021: 11).

Voucher material: 1 , Ülenurme $\left(58^{\circ} 19^{\prime} 3^{\prime \prime}\right.$ N, $26^{\circ} 43^{\prime} 23^{\prime \prime}$ E), 11-14.VIII.2020, H. Kirik leg., H. Kirik det., Mosquito Magnet trap, IZBE0210239, GenBank: OK465186; 1 \%, Ülenurme (58 $19^{\prime} 3^{\prime \prime}$ N, $26^{\circ} 43^{\prime} 23^{\prime \prime}$ E),

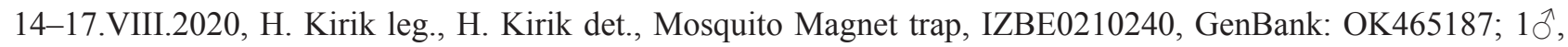
Tartu (58 21' 23" N, 26 44' 31" E), 17.IX.2017, T. Kesküla leg., H. Kirik det., sweep net, IZBE0210246.

Comment: 28 mosquitoes ( $0.1 \%$ of all specimens collected) were identified as Cs. annulata. These mosquitoes were found throughout the warm season, from May to October, and seem to have the longest period of activity of all of the Culiseta species in Estonia. The low number of individuals collected is likely to be due to collection bias.

\section{Culiseta (Culiseta) bergrothi (Edwards, 1921)}

(Fig. 5G)

Published source: Khalin et al. (2020: 74).

Voucher material: None.

Comment: One female of Cs. bergrothi collected in southeastern Estonia is preserved in the Zoological Institute of the Russian Academy of Sciences (Khalin \& Aibulatov 2020). This species was previously noted to be present in Estonia according to Fauna Europaea (Snow \& Ramsdale 2014), but the origin of that record is unknown as no other records have been found by the authors. Culiseta bergrothi has also been reported from provinces in northwestern Russia adjacent to Estonia (Khalin \& Aibulatov 2020), Finland (Culverwell 2018; Culverwell et al. 2021) and Sweden (Lundström et al. 2013).

\section{Notes on species not included in the list above}

\section{Genus Aedes Meigen, 1818}

\section{Aedes (Aedes) geminus Peus, 1970}

Published sources: None.

Voucher material: None.

Comment: Aedes geminus has been reported from Lithuania (Pakalniškis et al. 2000; Bernotienė \& Lučiūnaite 2011), a province in northwestern Russia adjacent to Estonia (Khalin \& Aibulatov 2020), Finland (Culverwell 2018; Culverwell et al. 2021) and Sweden (Lundström et al. 2013). Therefore, it may also be present in Estonia, but more work is needed to verify this, as the adult females of this species are difficult to distinguish from those of Ae. cinereus. 
Published sources: None.

Voucher material: None.

Comment: Aedes geniculatus has been reported from Lithuania (Pakalniškis et al. 2000), provinces in northwestern Russia adjacent to Estonia (Khalin \& Aibulatov 2020), Finland (Culverwell 2018; Culverwell et al. 2021) and Sweden (Lundström et al. 2013), and could be present in Estonia. This species probably has not been collected during fieldwork due to collection bias.

\section{Aedes (Ochlerotatus) euedes Howard, Dyar \& Knab, 1913}

Published sources: None.

Voucher material: None.

Comment: Aedes euedes is a member of the Ae. annulipes group. It reported from Lithuania (Pakalniškis et al. 2000), Latvia (Spungis 2000), provinces in northwestern Russia adjacent to Estonia (Khalin \& Aibulatov 2020), Finland (Culverwell 2018; Culverwell et al. 2021) and Sweden (Lundström et al. 2013). While no specimens have been reported from Estonia thus far, the species is likely to be present but overlooked, especially as this species appears to be much less common in the Nordic-Baltic region than Ae. annulipes and Ae. cantans, which also belong to the Ae. annulipes group (Khalin \& Aibulatov 2020; Lundström et al. 2013).

\section{Aedes (Ochlerotatus) pullatus (Coquillett, 1904)}

Published source: Kirik et al. (2021: 11).

Voucher material: None.

Comment: Mosquitoes with morphological characteristics most similar to Ae. pullatus were found during the study, but DNA barcoding identified them as Ae. communis. These specimens had scales on the hypostigmal area of the thorax, which is unusual for Ae. communis. Aedes pullatus has been previously reported from Lithuania (Pakalniškis et al. 2000), provinces in northwestern Russia adjacent to Estonia (Khalin \& Aibulatov 2020), Finland (Culverwell 2018; Culverwell et al. 2021) and Sweden (Lundström et al. 2013). However, the occurrence of this species in Estonia remains uncertain.

\section{Aedes (Ochlerotatus) punctodes Dyar, 1922}

Published sources: None.

Voucher material: None.

Comment: Females of Ae. punctodes are difficult to distinguish from the females of Ae. punctor. This species has been reported from Finland (Culverwell 2021) and Sweden (Lundström et al. 2013), and could also be present in Estonia, but this requires further research.

\section{Aedes (Rusticoidus) rusticus (Rossi, 1790)}

Published sources: None.

Voucher material: None.

Comment: Aedes rusticus has been recognized as a species in Estonia in several mosquito checklist (Khalin \& Aibulatov 2020; Snow \& Ramsdale 1999; Robert et al. 2019). However, as was pointed out by Huldén \& Huldén (2014) Ae. rusticus has been referred to historically by the synonym Ae. maculatus, but that name has also been mistakenly applied to Ae. cantans. In fact, the first checklist of mosquitoes in Estonia by H. Remm also included Ae. maculatus, but the number of specimens collected, as well as the description of their bionomics indicates that the species is Ae. cantans, not Ae. rusticus. This misunderstanding may be the reason why Ae. rusticus has been 
reported to be present in Estonia, although no verified specimens have been collected in the country. However, $A e$. rusticus has also been thought to be present in Lithuania (Pakalniškis et al. 2000) and Latvia (Spungis 2000), and has been reported from Sweden (Lundström et al. 2013). Therefore, this species could also be present in Estonia.

Genus Anopheles Meigen, 1818

Anopheles daciae Linton, Nicolescu \& Harbach, 2004 (in Nicolescu et al. 2004)

Published sources: None.

Voucher material: None.

Comment: It can be difficult to distinguish An. daciae from An. messeae based on morphology. Nucleotide polymorphisms in ITS2 sequences are currently the best way to distinguish these two species, but this was not done in this study. Anopheles daciae has been reported from Finland (Culverwell et al. 2020; Culverwell et al. 2021), and could also be present in Estonia.

\section{Discussion}

This is the first comprehensive update to the mosquito fauna of Estonia since the publication of the original checklist by Remm (1957). The new checklist was compiled based on 24,344 adult mosquitoes $(94.2 \%$ females) collected from 2008 to 2020, while also considering historic records and information from neighboring countries. Regrettably, mosquitoes collected by Remm, and used to compile the first checklist, have not been preserved and could not be verified. In total, the contemporary list includes 34 species, 27 of which were confirmed with voucher specimens; however, no specimens were collected to confirm the presence of seven other species in the country. All in all, additional collection efforts are required for a more thorough and detailed overview of the local mosquito fauna.

The updated checklist includes numerous changes compared to the historic list, which featured 30 species based on 12,204 mosquitoes (Remm 1957). Most importantly, four species were added to the list: An. messeae, Ae. hexodontus, Ae. sticticus and Cs. bergrothi. While the inclusion of the first three species is backed by numerous recently collected specimens, Cs. bergrothi is included based on a single specimen from Estonia stored at the Zoological Institute of the Russian Academy of Sciences (Khalin \& Aibulatov 2020). The possible occurrence of seven additional species, An. daciae, Ae. geminus, Ae. geniculatus, Ae. enedes, Ae. pullatus, Ae. punctodes and Ae. rusticus, was discussed. Those species are present in neighboring countries, but could not be included in the updated list without evidence to verify their presence in Estonia. Interestingly, when comparing the original checklist with the present one, the same four species have remained the most numerous, making up the majority of the specimens collected in both cases. Aedes communis remains the most common mosquito in Estonia, as it made up 29.7\% of all specimens collected in 1957 and $30.1 \%$ of all mosquitoes collected between 2008 and 2020 in the present study. Aedes communis is followed by Ae.punctor, Ae. cataphylla and mosquitoes of the Ae. annulipes group. It is important to note that all four species are most active during late spring or early summer: the first three are especially numerous during May, while members of the Ae. annulipes group tend peak in June. Naturally, there were also numerous differences in the abundance of various species between the two checklists, but it is unknown whether these were due to genuine change or merely because of differences in collection methods and study sites.

Several mosquito species are likely underrepresented in this study due to the chosen collection sites and methods of collection. In fact, the relatively low numbers of many Aedes, Anopheles, Culex and Culiseta species collected in this study are likely due to collection bias and further work is needed to understand their true abundance in Estonia. Also, study sites were mostly concentrated in southeastern Estonia, covering the areas of the eastern Lowlands and Drumlins, as well as the southern Uplands (Villoslada et al. 2017). Islands and the coast of the mainland were also covered, but require more long-term collecting effort to better understand how brackish water affects the local mosquito fauna. For example, it is clear that Ae. caspius is common in these areas, but other salinity tolerant species, for example Ae. dorsalis, require further research. It is likely that the makeup and bionomics of the costal mosquito fauna are markedly different from areas on the mainland. Collection sites of the current study generally mimicked the locations reported by Remm (1957). However, the central area of the mainland, including parts of the Central Estonian Plain, as well as the Pandivere Uplands and the Northern Plain (Villoslada et al. 2017), received little attention in both cases. It is also important to note that this research was based solely on active adult mosquitoes, the 
vast majority of which were females due to the chosen collection methods. In future, more work should be done to collect overwintering adults, which would allow for a more efficient collection of mosquito species that may not be attracted to baited traps. Moreover, collections larvae would not only improve the checklist, but would also provide additional information about the ecology of the species. It would likewise be beneficial to collect more male mosquitoes. While males do not require blood meals and are thus far less studied, they provide additional verification of the occurrence of some species. For example, the presence of Ae. diantaeus, which is morphologically similar to both Ae. intrudens and Ae.communis, was finally verified in Estonia based on a male specimen. Also, many female mosquitoes of the Ae. annulipes group can be difficult to identify due to overlapping morphological characteristics, as well as inconclusive results of DNA barcoding. However, it is relatively easy to distinguish the males of these species based on structures of their genitalia.

An updated checklist allows for a better understanding of the mosquito-borne pathogens circulating among local dipterans. For example, tularemia is a disease caused by the bacterium Francisella tularensis (McCoy \& Chapin), which occurs throughout the northern hemisphere. It manifests in humans with influenza-like symptoms and numerous other ailments, based on the route of infection (Maurin \& Gyuranecz 2016). Francisella tularensis is normally confined to animals on a few islands of Estonia, but one or two human infections occur in the country almost every year (Health Board 2012, 2016, 2020). Although mosquitoes are one of several arthropods capable of transmitting the bacterium, natural infections have been detected in Ae. cinereus, Ae. communis, Ae. punctor, Ae. sticticus, Ae. vexans and Cx. pipiens (Lundström et al. 2011; Dryselius et al. 2019). Furthermore, the filarial nematode Dirofilaria repens Railliet \& Henry appears to also have become established in Estonia, since it has been found in local dogs several times since 2008 (Jokelainen et al. 2016). The mosquito-borne Dirofilaria repens normally parasitizes subcutaneous tissues of carnivores and is often asymptomatic in dogs, but can also infect humans, resulting in skin nodules, ocular dirofilariasis or other complications (Capelli et al. 2018; Ciuca et al. 2020; Pupić-Bakrač et al. 2021). In fact, autochthonous human cases have already been reported in countries neighboring Estonia (Melbarde-Gorkusa et al. 2011; Pietikäinen et al. 2017). Thus far, numerous species belonging to the genera Aedes, Anopheles, Coquillettidia and Culex have been indicated in carrying Dirofilaria repens, as reported by Kronefeld et al. (2014), Kemenesi et al. (2015), Șuleșco et al. (2016) and Shaikevich et al. (2019a). Importantly, Shaikevich et al. (2019a) found that Ae. communis could be one of the species effective in spreading Dirofilaria species in Russia. Additionally, there are also some mosquito-borne viruses circulating in northern Europe (Francy et al. 1989; Barzon 2018). For example, Sindbis virus, which is carried long distances by migrating birds and transmitted to humans by mosquitoes, is especially noteworthy in the Nordic countries (Kurkela et al. 2005; Bergqvist et al. 2015), but the virus has also been isolated from birds in Estonia (Uryvaev et al. 1992). Generally, ornithophilic species like $C x$. pipiens, Cx. torrentium and Cs. morsitans are thought to be important carriers of the Sindbis virus (Francy et al. 1989). Based on this information, Ae. communis, which is overall the most numerous mosquito in Estonia, and $C x$. pipiens/torrentium, which are especially active at the end of summer, are the most likely species to become important vectors in the country.

There are still notable caps in our knowledge of mosquito diversity in Estonia, as biting dipterans were largely ignored during the latter half of the last century and the country still lacks a continuous mosquito monitoring program. Furthermore, scenarios of climate change predict that the annual mean temperature is likely to increase by $2.3-4.5^{\circ} \mathrm{C}$ in Estonia by the year 2100, and during the same time the average yearly precipitation could increase anywhere between $4-46 \%$ (Kont et al. 2003). This will likely influence the length of time suitable for mosquito development, as well as the availability of larval habitats in the country. Also, it is well known that alterations in land use, international trade and travel have led to changes in the diversity and distribution of various arthropods, including many mosquitoes (Brugueras et al. 2020; Medlock et al. 2012; Rochlin et al. 2016; Brugueras et al. 2020). Hence, there is a clear need for further studies on both blood-sucking dipterans and insect-borne pathogens in Estonia. Extra attention should be paid to the international airport and large harbors, which can act as entry points for non-native mosquitoes (Sukehiro et al. 2013; Ibáñez-Justicia et al. 2020). Furthermore, mosquito collection activities should be more evenly spread out in Estonia to sample as many biotypes as possible. Finally, insect-borne pathogens require more attention. For example, how important mosquitoes are in transmitting Francisella tularensis in the region and which species carry Dirofilaria repens in Estonia remains to be investigated. 


\section{Acknowledgements}

This study was made possible by the Estonian Research Council project IUT21-1, the Estonian University of Life Sciences grants 8P160014VLVP and 8-2/T14143VLVP and the Estonian Agricultural Registers and Information Board project L170171PKZO. Additional funding was received from the Ministry of Education and Research project 8-2/T9041PKZO. Special thanks to Viktoria Burtin for her efforts in collecting and identifying mosquitoes and restarting the study of blood-feeding dipterans in Estonia. The authors would also like to thank Tõnu Kesküla, Valentina Oborina and Airi Külvet for their considerable help in gathering specimens. Additional gratitude is expressed to Anu Merilo for barcoding mosquitoes of the An. maculipennis complex and to everyone who allowed insect traps to be used on their property. The authors are immensely grateful to everyone who donated their time and/or mosquito specimens to this research. The authors would also like to thank the two anonymous reviewers who suggested many valuable improvements to the manuscript.

\section{References}

Adams, C.F. (1903) Dipterological contributions. Kansas University Science Bulletin, 2 (2), 21-47.

Bale, J.F. (2012) Emerging viral infections. Seminars in Pediatric Neurology, 19 (3), 152-157. https://doi.org/10.1016/j.spen.2012.02.001

Barzon, L. (2018) Ongoing and emerging arbovirus threats in Europe. Journal of Clinical Virology, 107, 38-47. https://doi.org/10.1016/j.jcv.2018.08.007

Beck, H.E., Zimmermann, N.E., McVicar, T.R., Vergopolan, N., Berg, A. \& Wood, E.F. (2018). Present and future Köppen-Geiger climate classification maps at 1-km resolution. Scientific Data, 5, 180214. https://doi.org/10.1038/sdata.2018.214

Becker, N., Petrić, D., Zgomba, M., Boase, C., Madon, M.B., Dahl, C. \& Kaiser, A. (2020) Mosquitoes: identification, ecology and control. Third Edition. Springer Nature, Cham, xxxi $570 \mathrm{pp}$. https://doi.org/ 10.1007/978-3-030-11623-1

Bergman, A. \& Hesson, J.C. (2021) Wolbachia prevalence in the vector species Culex pipiens and Culex torrentium in a Sindbis virus-endemic region of Sweden. Parasites \& Vectors, 14, 428. https://doi.org/10.1186/s13071-021-04937-6

Bergqvist, J., Forsman, O., Larsson, P., Näslund, J., Lilja, T., Engdahl, C., Lindström, A., Gylfe, Å., Ahlm, C., Evander, M. \& Bucht, G. (2015) Detection and isolation of Sindbis virus from mosquitoes captured during an outbreak in Sweden, 2013. Vector-Borne and Zoonotic Diseases, 15 (2), 133-140. https://doi.org/10.1089/vbz.2014.1717

Bernotienè, R. \& Lučiūnaite, V. (2011) Mosquito (Diptera: Culicidae) species new for Lithuanian fauna. New and Rare for Lithuania Insect Species, 23, 99-100.

Braig, H.R., Zhou, W.G., Dobson, S.L. \& O’Neill, S.L. (1998) Cloning and characterization of a gene encoding the major surface protein of the bacterial endosymbiont Wolbachia pipientis. Journal of Bacteriology, 180, 2373-2378. https://doi.org/10.1128/jb.180.9.2373-2378.1998

Brugueras, S., Fernández-Martínez, B., Martínez-de la Puente, J., Figuerola, J., Porro, T.M., Rius, C., Larrauri, A. \& GómezBarroso, D. (2020) Environmental drivers, climate change and emergent diseases transmitted by mosquitoes and their vectors in southern Europe: A systematic review. Environmental Research, 191, 1-17. https://doi.org/10.1016/j.envres.2020.110038

Burtin, V. (2014) Pistesääsklaste (Diptera: Culicidae) liigiline koosseis ja elupaigaeelistused Tartu linnas [Mosquito (Diptera: Culicidae) species richness and habitat preference in the town of Tartu]. Estonian University of Life Sciences, Tartu, 64 pp.

Câmara, D.C.P., Pinel, C. da S., Rocha, G.P., Codeço, C.T. \& Honório, N.A. (2020) Diversity of mosquito (Diptera: Culicidae) vectors in a heterogeneous landscape endemic for arboviruses. Acta Tropica, 212, 105715. https://doi.org/10.1016/j.actatropica.2020.105715

Capelli, G., Genchi, C., Baneth, G., Bourdeau, P., Brianti, E., Cardoso, L., Danesi, P., Fuehrer, H.P., Giannelli, A., Ionică, A.M., Maia, C., Modrý, D., Montarsi, F., Krücken, J., Papadopoulos, E., Petrić, D., Pfeffer, M., Savić, S., Otranto, D., Poppert, S. \& Silaghi, C. (2018) Recent advances on Dirofilaria repens in dogs and humans in Europe. Parasites \& Vectors, $11,663$. https://doi.org/10.1186/s13071-018-3205-x

Ciuca, L., Vismarra, A., Lebon, W., Beugnet, F., Morchon, R., Rinaldi, L., Cringoli, G., Kramer, L. \& Genchi, M. (2020) New insights into the biology, diagnosis and immune response to Dirofilaria repens in the canine host. Veterinary Parasitology, $277,1-7$. https://doi.org/10.1016/j.vpoa.2020.100029

Coquillett, D.W. (1904) New North American Diptera. Proceedings of the Entomological Society of Washington, 6 (3), $166-$ 192. 
Culverwell, C.L. (2018) A report on the mosquitoes of mainland Åland, southwestern Finland and revised list of Finnish mosquitoes. Medical and Veterinary Entomology, 32 (2), 145-154.

https://doi.org/10.1111/mve.12272

Culverwell, C.L., Uusitalo, R.J., Korhonen, E.M., Vapalahti, O.P., Huhtamo, E. \& Harbach, R.E. (2021). The mosquitoes of Finland: updated distributions and bionomics. Medical and Veterinary Entomology, 35 (1), 1-29. https://doi.org/10.1111/mve.12475

Culverwell, C.L., Vapalahti, O.P. \& Harbach, R.E. (2020) Anopheles daciae, a new country record for Finland. Medical and Veterinary Entomology, 34 (2), 145-150. https://doi.org/10.1111/mve.12431

de Geer, C. (1776) Memoires pour servir a l'histoire des insectes. Tome sixieme. De l'imprimerie de Pierre Hesselberg, Stockholm, viii +522 pp., 30 pls. https://doi.org/10.5962/bhl.title.14146

Dryselius, R., Hjertqvist, M., Mäkitalo, S., Lindblom, A., Lilja, T., Eklöf, D. \& Lindström, A. (2019) Large outbreak of tularaemia, central Sweden, July to September 2019. Eurosurveillance, 24 (42), 1-5. https://doi.org/10.2807/1560-7917.ES.2019.24.42.1900603

Dyar, H.G. (1905) Remarks on genitalic genera in the Culicidae. Proceedings of the Entomological Society of Washington, 7 (1), 42-49.

Dyar, H.G. (1916) New Aedes from the mountains of California (Diptera, Culicidae). Insecutor Inscitiae Menstruus, 4 (7-9), $80-90$.

Dyar, H.G. (1919) Westward extension of the Canadian mosquito fauna (Diptera, Culicidae). Insecutor Inscitiae Menstruus, 7 (1-3), 11-39.

Dyar, H.G. (1922) New mosquitoes from Alaska (Diptera, Culicidae). Insecutor Inscitiae Menstruus, 10 (1-3), 1-3.

Dyar, H.G. (1924) A new mosquito from Siberia (Diptera, Culicidae). Insecutor Inscitiae Menstruus, 12, $127-128$.

Dyar, H.G. \& Knab, F. (1907) Descriptions of three new North American mosquitoes. Journal of the New York Entomological Society, 15 (4), 213-214.

Eckstein, F. (1918) Zur Systematik der einheimischen Stechmücken. Zentralblatt fur Bakteriologie, Abt. 1, Originale, 82 (2), 57-68.

Edwards, F.W. (1921) A synonymic list of the mosquitoes hitherto recorded from Sweden, with keys for determining the genera and species. Entomologisk Tidskrift, 42 (1), 46-52.

Environment Agency (2020) Statistiline metsainventuur (SMI) 2019. National Forest Inventory (NFI), Tallinn. Available from: https://keskkonnaagentuur.ee/keskkonnaagentuuri-tegevusvaldkonnad/mets/smi (accessed 28 October 2021)

Eurostat (2021) Population density. EC Data Browser. Available from: https://ec.europa.eu/eurostat/databrowser/view/tps00003/ default/table?lang=en (accessed 28 September 2021)

Evans, A.B. \& Peterson, K.E. (2019) Throw out the map: neuropathogenesis of the globally expanding California serogroup of Orthobunyaviruses. Viruses, 11 (9), 1-20. https://doi.org/10.3390/v11090794

Falleroni, D. (1926) Fauna anofelica italiana e suo "habitat,, (paludi, risaie, canali). Metodi di lotta contro la malaria. Rivista di Malariologia, 5 (5-6), 553-593.

Felt, E.P. (1904) Mosquitos or Culicidae of New York State. New York State Museum Bulletin, 79 (323), 241-391, 57 pls., $391 \mathrm{a}-391 \mathrm{f}+393-400$.

Ficalbi, E. (1889) Notizie preventive sulle zanzare italiane. II ${ }^{\mathrm{a}}$ Nota preventiva (1). Descrizione di una specie nuova. Bullettino della Società Entomologica Italiana, 21, 50-53.

Foley, D.H., Rueda, L.M. \& Wilkerson, R.C. (2007) Insight into global mosquito biogeography from country species records. Journal of Medical Entomology, 44 (4), 554-567. https://doi.org/10.1603/0022-2585(2007)44[554:IIGMBF]2.0.CO;2

Folmer, O., Black, M., Hoeh, W., Lutz, R. \& Vrijenhoek, R. (1994) DNA primers for amplification of mitochondrial cytochrome c oxidase subunit I from diverse metazoan invertebrates. Molecular Marine Biology and Biotechnology, 3 (5), $294-299$.

Francy, D.B., Jaenson, T.G.T., Lundström, J.O., Schildt, E.B., Espmark, Å., Henriksson, B. \& Niklasson, B. (1989) Ecologic studies of mosquitoes and birds as hosts of Ockelbo virus in Sweden and isolation of Inkoo and Batai viruses from mosquitoes. American Journal of Tropical Medicine and Hygiene, 41 (3), 355-363. https://doi.org/10.4269/ajtmh.1989.41.355

Franklinos, L.H.V., Jones, K.E., Redding, D.W. \& Abubakar, I. (2019) The effect of global change on mosquito-borne disease. Lancet Infectious Diseases, 19 (9), 302-312. https://doi.org/10.1016/S1473-3099(19)30161-6

Gornostaeva, R.M. (2000) A revised checklist of the mosquitoes (Diptera: Culicidae) of European Russia. European Mosquito Bulletin, 6, 15-19.

Hall, T.A. (1999) BioEdit: a user-friendly biological sequence alignment editor and analysis program for Windows 95/98/NT. Nucleic Acids Symposium Series, 41, 95-98. https://doi.org/citeulike-article-id:691774

Harbach, R.E., Dallimore, T., Briscoe, A.G., Culverwell, C.L., Vaux, A.G.C. \& Medlock, J.M. (2017) Aedes nigrinus (Eckstein, 1918) (Diptera, Culicidae), a new country record for England, contrasted with Aedes sticticus (Meigen, 1838). ZooKeys, $671,119-130$. 
https://doi.org/10.3897/zookeys.671.12477

Health Board (2012) s.n. In: Epštein, J., Kutsar, K., Kerbo, N. \& Aro, T. (Eds.), Communicable disease statistics in Estonia. Part 15. Available from: https://www.terviseamet.ee/sites/default/files/content-editor/vanaveeb/Kasulikku/ Nakkushaigused/stat_15.pdf (accessed 28 October 2021)

Health Board (2016) s.n. In: Epštein, J., Kutsar, K., Kerbo, N. \& Aro, T. (Eds.), Communicable disease statistics in Estonia. Part 16. Available from: https://www.terviseamet.ee/sites/default/files/content-editor/vanaveeb/Kasulikku/ Nakkushaigused/Stat_16_2015.pdf (accessed 28 October 2021)

Health Board (2020) s.n. In: Epštein, J. \& Kerbo, N. (Eds.), Communicable disease statistics in Estonia. Part 17. J. Available from: https://www.terviseamet.ee/en/communicable-diseases/communicable-disease-bulletins (accessed 28 October 2021)

Howard, L.O., Dyar, H.G. \& Knab, F. (1913) The mosquitoes of North and Central America and the West Indies. Vols. 1 \& 2. Carnegie Institution of Washington Publication No. 159. The Lord Baltimore Press, Baltimore, vii +520 pp., x +150 pls. [for 1912]

Hui, E.K.-W. (2006) Reasons for the increase in emerging and re-emerging viral infectious diseases. Microbes and Infection, 8 (3), 905-916. https://doi.org/10.1016/j.micinf.2005.06.032

Huldén, L. \& Huldén, L. (2014) Checklist of the family Culicidae (Diptera) in Finland. ZooKeys, 441, 47-51. https://doi.org/10.3897/zookeys.441.7743

Ibáñez-Justicia, A., Smitz, N., Den Hartog, W., de Vossenberg, B. van, De Wolf, K., Deblauwe, I., Van Bortel, W., Jacobs, F., Vaux, A.G.C., Medlock, J.M. \& Stroo, A. (2020) Detection of exotic mosquito species (Diptera: Culicidae) at international airports in europe. International Journal of Environmental Research and Public Health, 17 (10), 3450. https://doi.org/10.3390/ijerph17103450

Inácio da Silva, L.M., Dezordi, F.Z., Paiva, M.H.S. \& Wallau, G.L. (2021) Systematic review of Wolbachia symbiont detection in mosquitoes: an entangled topic about methodological power and true symbiosis. Pathogens, 10 (1), 39. https://doi.org/10.3390/pathogens10010039

Islam, J., Zaman, K., Duarah, S., Raju, P.S. \& Chattopadhyay, P. (2017) Mosquito repellents: an insight into the chronological perspectives and novel discoveries. Acta Tropica, 167, 216-230. https://doi.org/10.1016/j.actatropica.2016.12.031

Jokelainen, P., Mõtsküla, P.F., Heikkinen, P., Ülevaino, E., Oksanen, A. \& Lassen, B. (2016) Dirofilaria repens microfilaremia in three dogs in Estonia. Vector-Borne and Zoonotic Diseases, 16 (2), 136-138. https://doi.org/10.1089/vbz.2015.1833

Kemenesi, G., Kurucz, K., Kepner, A., Dallos, B., Oldal, M., Herczeg, R., Vajdovics, P., Bányai, K. \& Jakab, F. (2015) Circulation of Dirofilaria repens, Setaria tundra, and Onchocercidae species in Hungary during the period 2011-2013. Veterinary Parasitology, 214 (1-2), 108-113. https://doi.org/10.1016/j.vetpar.2015.09.010

Khalin, A.V. \& Aibulatov, S.V. (2020) Fauna of blood-sucking insects of the gnus complex in the Northwestern Region of Russia. III. Mosquitoes (Culicidae). Entomological Review, 100 (1), 58-82. https://doi.org/10.1134/S0013873820010066

Khalin, A.V. \& Aibulatov, S.V. (2021) Northernmost records of mosquito species (Diptera: Culicidae) in northwestern Russia. Zoosystematica Rossica, 30 (1), 46-63. https://doi.org/10.31610/ZSR/2021.30.1.46

Kirby, W. (1837) Fauna Boreali-Americana. Part IV. The Insects. In: Richardson, J. (ed.), Fauna Boreali-Americana; or the Zoology of the northern parts of British America: containing descriptions of the objects of natural history collected on the late Northern Land Expeditions, under command of Captain Sir John Franklin, R.N. Josiah Fletcher, Norwich, xxxix + 325 pp., 13 pls, errata.

Kirik, H., Burtin, V., Tummeleht, L. \& Kurina, O. (2021) Friends in all the green spaces: weather dependent changes in urban mosquito (Diptera: Culicidae) abundance and diversity. Insects, 12 (4), 352. https://doi.org/10.3390/insects 12040352

Kirik, H., Tummeleht, L., Lilja, T. \& Kurina, O. (2020) Novel mitochondrial DNA lineage found among Ochlerotatus communis (De Geer, 1776) of the Nordic-Baltic Region. Insects, 11 (6), 397. https://doi.org/10.3390/insects 11060397

Kont, A., Jaagus, J. \& Aunap, R. (2003) Climate change scenarios and the effect of sea-level rise for Estonia. Global and Planetary Change, $36(1-2), 1-15$. https://doi.org/10.1016/S0921-8181(02)00149-2

Kottek, M., Grieser, J., Beck, C., Rudolf, B. \& Rubel, F. (2006) World map of the Köppen-Geiger climate classification updated. Meteorologische Zeitschrift, 15 (3), 259-263. https://doi.org/10.1127/0941-2948/2006/0130

Kronefeld, M., Kampen, H., Sassnau, R. \& Werner, D. (2014) Molecular detection of Dirofilaria immitis, Dirofilaria repens and Setaria tundra in mosquitoes from Germany. Parasites \& Vectors, 7, 30 https://doi.org/10.1186/1756-3305-7-30

Kurkela, S., Manni, T., Myllynen, J., Vaheri, A. \& Vapalahti, O. (2005) Clinical and laboratory manifestations of Sindbis virus 
infection: prospective study, Finland, 2002-2003. Journal of Infectious Diseases, 191 (11), 1820-1829.

https://doi.org/10.1086/430007

Liang, G., Gao, X. \& Gould, E.A. (2015) Factors responsible for the emergence of arboviruses; strategies, challenges and limitations for their control. Emerging Microbes \& Infections, 4 (1), 1-5. https://doi.org/10.1038/emi.2015.18

Lilja, T., Troell, K., Kirik, H. \& Lindström, A. (2018) A distinct group of north European Aedes vexans as determined by mitochondrial and nuclear markers. Medical and Veterinary Entomology, 32 (3), 282-289. https://doi.org/10.1111/mve.12294

Linnaeus, C. (1758) Systema naturae per regna tria naturae, secundum classes, ordines, genera, species, cum characteribus, differentiis, synonymis, locis. Tomus 1. Editio Decima. Impensis Direct. Laurentii Salvii, Holmiae, 824 pp. https://doi.org/10.5962/bhl.title.559

Ludlow, C.S. (1906) An Alaskan mosquito. Canadian Entomologist, 38 (10), 326-328. https://doi.org/10.4039/ent38326-10

Ludlow, C.S. (1920) New Siberian Culicidae (Diptera) [sic]. Insecutor Inscitiae Menstruus, 7 (10-12), 151-161. [for 1919]

Lundström, J.O., Andersson, A.-C., Bäckman, S., Schäfer, M.L., Forsman, M. \& Thelaus, J. (2011) Transstadial transmission of Francisella tularensis holarctica in mosquitoes, Sweden. Emerging Infectious Diseases, 17 (5), 794-799. https://doi.org/10.3201/eid1705.100426

Lundström, J.O., Schäfer, M.L., Hesson, J.C., Blomgren, E., Lindström, A., Wahlqvist, P., Halling, A., Hagelin, A., Ahlm, C., Evander, M., Broman, T., Forsman, M. \& Persson Vinnersten, T.Z. (2013) The geographic distribution of mosquito species in Sweden. Journal of the European Mosquito Control Association, 31, 21-35.

Martinet, J.-P., Ferté, H., Failloux, A.-B., Schaffner, F. \& Depaquit, J. (2019) Mosquitoes of north-western Europe as potential vectors of arboviruses: A review. Viruses, 11 (11), 1059. https://doi.org/10.3390/v11111059

Martini, E. (1925) Zwei bemerkenswerte Culiciden von einem eigenartigen Biotop. Internationale Revue der gesamte Hydrobiologie und Hydrographie, 12 (5/6), 333-337.

Maurin, M. \& Gyuranecz, M. (2016) Tularaemia: clinical aspects in Europe. Lancet Infectious Diseases, 16 (1), $113-124$. https://doi.org/10.1016/S1473-3099(15)00355-2

Medlock, J.M., Hansford, K.M., Schaffner, F., Versteirt, V., Hendrickx, G., Zeller, H. \& Van Bortel, W. (2012) A review of the invasive mosquitoes in Europe: ecology, public health risks, and control options. Vector-Borne and Zoonotic Diseases, 12 (6), 435-447.

https://doi.org/10.1089/vbz.2011.0814

Meigen, J.W. (1804) Klassifikazion und Beschreibung der europäischen Zweiflügeligen Insekten. (Diptera Linn.). Erster Band. Ester Abtheilung, mit VIII Kupfertafeln. Karl Reichard, Braunschweig, xxviii +152 pp., 8 pls. https://doi.org/10.5962/bhl.title.12464

Meigen, J.W. (1818) Systematische Beschreibung der bekannten europäischen zweiflügeligen Insekten. Vol. 1. Bei Friedrich Wilhelm Forstmann, Aachen, xxxvi $+332+1$ (errata) pp., 11 pls. https://doi.org/10.5962/bhl.title.12464

Meigen, J.W. (1830) Systematische Beschreibung der bekannten europäischen zweiflügeligen Insekten. Vol. 6. Schulzische Buchhandlung, Hamm, iv +401 pp., 12 pls. https://doi.org/10.5962/bhl.title.12464

Meigen, J.W. (1838) Systematische Beschreibung der bekannten europaeischen zweifluegeligen Insekten. Vol. 7. Hamm, xii + 434 pp., 8 pls. https://doi.org/10.5962/bhl.title.12464

Melbarde-Gorkusa, I., Abolins, A., Strumfa, I., Martinsons, A. \& Gardovskis, J. (2011) Human Dirofilariasis in Latvia-the first case in surgical practice. Acta Chirurgica Latviensis, 11, 172-174. https://doi.org/10.2478/v10163-012-0037-1

Möhlmann, T.W.R., Wennergren, U., Tälle, M., Favia, G., Damiani, C., Bracchetti, L. \& Koenraadt, C.J.M. (2017). Community analysis of the abundance and diversity of mosquito species (Diptera: Culicidae) in three European countries at different latitudes. Parasites \& Vectors, 10, 510. https://doi.org/10.1186/s13071-017-2481-1

Müller, O.F. (1764) Fauna insectorum Fridrichsdalina, sive methodica descriptio insectorum agri Fridrichsdalensis, cum characteribus genericis et specificis, nominibus trivialibus, locis natalibus, iconibus allegatis, novisque pluribus speciebus additis. Hafniae et Lipsiae, xxiv +96 pp.

Nicolescu, G., Linton, Y.-M., Vladimirescu, A., Howard, T.M. \& Harbach, R.E. (2004) Mosquitoes of the Anopheles maculipennis group (Diptera: Culicidae) in Romania, with the discovery and formal recognition of a new species based on molecular and morphological evidence. Bulletin of Entomological Research, 95 (6), 525-535. https://doi.org/10.1079/BER2004330

Olivier, M. (1791) Encyclopedique méthodique. Histoire naturelle. Insectes. Vol. 6. Panckoucke, Paris, [4] + 704 pp. https://doi.org/10.5962/bhl.title.82248

Pakalniškis, S., Rimšaitè, J., Sprangauskaitė-Bernotienè, R., Butautaitè, R. \& Podènas, S. (2000) Checklist of Lithuanian Diptera. Acta Zoologica Lituanica, 10, 3-58. 
https://doi.org/10.1080/13921657.2000.10512316

Pallas, P.S. (1771) Reise durch versehiedene Provinzen des Russischen Reichs. Volume 1. Kayserliche Academie der Wissenschaften, St Petersburg, [12] + 504 pp., tabs. I-XI, tabs. A-L.

Peus, F. (1935) Theobaldia (Subg. Culicella) ochroptera sp. n., eine bisher unbekannte Stechmücke. Markische Tierwelt: Zeitschrift für die faunistische Erforschung der Kurmark, 1, 113-121.

Peus, F. (1970) Bemerkenswerte Mücken am Tegeler Fliess. Berliner Naturschutzblätter, May (Special Issue), 18-26.

Pietikäinen, R., Nordling, S., Jokiranta, S., Saari, S., Heikkinen, P., Gardiner, C., Kerttula, A.M., Kantanen, T., Nikanorova, A., Laaksonen, S., Lavikainen, A. \& Oksanen, A. (2017) Dirofilaria repens transmission in southeastern Finland. Parasites \& Vectors, 10, 561. https://doi.org/10.1186/s13071-017-2499-4

Pupić-Bakrač, A., Pupić-Bakrač, J., Beck, A., Jurković, D., Polkinghorne, A. \& Beck, R. (2021) Dirofilaria repens microfilaremia in humans: case description and literature review. One Health, 13, 1-8. https://doi.org/10.1016/j.onehlt.2021.100306

Ratnasingham, S. \& Hebert, P.D.N. (2007) BOLD: The Barcode of Life Data System (www.barcodinglife.org). Molecular Ecology Notes, 7, 355-364. https://doi.org/10.1111/j.1471-8286.2006.01678.x

Raukas, A. (1995) Eesti. Loodus [Estonia. Nature]. Valgus Publishers; Estonian Encyclopaedia Publishers, Tallinn, 606 pp.

Remm, H. (1955) Eesti NSV verdimevate kahetiivaliste fauna [Blood-sucking Diptera fauna of Estonian SSR]. Tartu State University, Tartu, $229 \mathrm{pp}$.

Remm, H. (1957) On the fauna and ecology of mosquitoes (Diptera, Culicidae) of Estonian SSR [in Russian]. Entomologicheskoe Obozrenie, 36, 148-160.

Robert, V., Günay, F., Goff, G.L., Boussès, P., Sulesco, T., Khalin, A.V., Medlock, J.M., Kampen, H., Petrić, D. \& Schaffner, F. (2019) Distribution chart for Euro-Mediterranean mosquitoes (Western Palaearctic region). Journal of the European Mosquito Control Association, 37, 1-29.

Rochlin, I., Faraji, A., Ninivaggi, D.V., Barker, C.M. \& Kilpatrick, A.M. (2016) Anthropogenic impacts on mosquito populations in North America over the past century. Nature Communications, 7, 13604. https://doi.org/10.1038/ncomms13604

Rossi, P. (1790) Fauna Etrusca: Sistens insecta quae in provinciis Florentina et Pisana praesertim collegit Petrus Rossius. Vol. 2. Thomae Masi \& Sociorum, Liburni, 348 pp., 10 pls.

Sammet, K., Talvi, T., Süda, I. \& Kurina, O. (2016) Pseudoscorpions (Arachnida: Pseudoscorpiones) in Estonia: new records and an annotated checklist. Entomologica Fennica, 27 (4), 149-163. https://doi.org/10.33338/ef.60259

Scholte, E.-J., den Hartog, W. \& Reusken, C. (2011) A report of Anopheles algeriensis (Diptera: Culicidae) from The Netherlands. Entomologische Berichten, 71 (2), 39-42.

Schäfer, M.L. \& Lundström, J.O. (2009) The present distribution and predicted geographic expansion of the floodwater mosquito Aedes sticticus in Sweden. Journal of Vector Ecology, 34 (1), 141-147. https://doi.org/10.3376/038.034.0117

Shaikevich, E., Bogacheva, A. \& Ganushkina, L. (2019a) Dirofilaria and Wolbachia in mosquitoes (Diptera: Culicidae) in central European Russia and on the Black Sea coast. Parasite, 26, 2. https://doi.org/10.1051/parasite/2019002

Shaikevich, E., Bogacheva, A., Rakova, V., Ganushkina, L. \& Ilinsky, Y. (2019b) Wolbachia symbionts in mosquitoes: intraand intersupergroup recombinations, horizontal transmission and evolution. Molecular Phylogenetics and Evolution, 134, 24-34. https://doi.org/10.1016/j.ympev.2019.01.020

Schrank, Franz von Paula. (1776) Beyträge zur Naturgeschichte. Caspar Fritsch, Leipzig, [6] + 137 + [3] pp., 7 foldout pls.

Snow, K. \& Ramsdale, C. (1999) Distribution chart for European mosquitoes. European Mosquito Bulletin, 3, 14-31.

Snow, K.R. \& Ramsdale, C.D. (2014) Fauna Europaea: Culicidae. In: Beuk, P. \& Pape, T. (Eds), Fauna Europaea: Diptera. Fauna Europaea Version 2017.06. Available from: https://fauna-eu.org (accessed 26 October 2021)

Spungis, V. (2000) A checklist of Latvian mosquitoes (Diptera, Culicidae). Journal of the European Mosquito Control Association, 6, 8-11.

Statistics Estonia (2020) Main indicators. Available from: https://www.stat.ee/en/find-statistics/main-indicators (accessed 28 September 2021)

Stephens, J.F. (1825) Some observations on the British Tipulidae, together with descriptions of the species of Culex and Anopheles found in Britain. Zoological Journal, 1 (4), 448-457.

Stephens, J.F. (1828) Note on the foregoing paper, with a description of a new species of Anopheles. Zoological Journal, 3 (12), $502-504$.

Sukehiro, N., Kida, N., Umezawa, M., Murakami, T., Arai, N., Jinnai, T., Inagaki, S., Tsuchiya, H., Maruyama, H. \& Tsuda, Y. (2013) First report on invasion of yellow fever mosquito, Aedes aegypti, at Narita International Airport, Japan in August 2012. Japanese Journal of Infectious Diseases, 66 (3), 189-194. https://doi.org/10.7883/yoken.66.189

Şuleșco, T., Volkova, T., Yashkova, S., Tomazatos, A., von Thien, H., Lühken, R. \& Tannich, E. (2016) Detection of Dirofilaria repens and Dirofilaria immitis DNA in mosquitoes from Belarus. Parasitology Research, 115 (9), 3535-3541. 
https://doi.org/10.1007/s00436-016-5118-y

Sundseth, K., Finne, A., Houston, J. \& Eriksson, M. (2009) s.n. In: Wegefelt, S. (Ed.), Natura 2000 in the Boreal Region. Office for Official Publications of the European Communities, Luxembourg, pp. 1-11.

Theobald, F.V. (1901) A monograph of the Culicidae or mosquitoes. Vol. 2. British Museum (Natural History), London, viii + $391 \mathrm{pp}$. https://doi.org/10.5962/bhl.title.58067

Theobald, F.V. (1903) A monograph of the Culicidae or mosquitoes. Volume 3. British Museum (Natural History), London, xvii $+[1]($ errata $)+359$ pp., foldout table, 17 pls.

Tomasson, K., Tammaru, T. \& Kurina, O. (2014) Harvestmen (Arachnida: Opiliones) in Estonia: results of the Estonian Malaise Trap Project. Entomologica Fennica, 25 (3), 142-156. https://doi.org/10.33338/ef.48267

Uryvaev, L.V., Vasilenko, V.A., Parasiuk, N.A., Ionova, K.S., Gushchina, E.A., Kullapere, A., Leibak, E. \& Lvov, D.K. (1992) The isolation and identification of the Sindbis virus from migratory birds in Estonia. Voprosy Virusologii, 37 (1), 67-70. [in Russian]

Villoslada, M., Bunce, R.G.H., Sepp, K., Jongman, R.H.G., Metzger, M.J., Kull, T., Raet, J., Kuusemets, V., Kull, A. \& Leito, A. (2017) A framework for habitat monitoring and climate change modelling: construction and validation of the Environmental Stratification of Estonia. Regional Environmental Change, 17, 335-349. https://doi.org/10.1007/s10113-016-1002-7

Walker, F. (1856) Insecta Saundersiana: or characters of undescribed insects in the collection of William Wilson Saunders, Esq., F.R.S., F.L.S., \&c. Vol. I. Diptera. John van Voorst, London, 474 pp., 8 pls. https://doi.org/10.5962/bhl.title.5112

WHO (2014) A global brief on vector-borne diseases. Available from: https://apps.who.int/iris/handle/10665/111008 (accessed 28 October 2021)

WHO(2017)Globalvectorcontrol response2017-2030.Available from:https://www.who.int/publications/i/item/9789241512978 (accessed 28 October 2021)

Zell, R., Krumbholz, A. \& Wutzler, P. (2008) Impact of global warming on viral diseases: what is the evidence? Current Opinion in Biotechnology, 19 (6), 652-660. https://doi.org/10.1016/j.copbio.2008.10.009 